\title{
0 estado de necessidade no Código Penal brasileiro: uma proposta de modelo diferenciador
}

\section{The necessity defense in brazilian Penal Code: a differentiating model scheme}

\section{Gustavo de Oliveira Quandt}

Resumo: 0 artigo analisa os problemas da teoria unitária justificante e dos modelos diferenciadores utilizados em doutrina para explicar 0 alcance do art. 24 do Código Penal brasileiro. Procura demonstrar que a teoria unitária aparentemente adotada pela lei importa na distorção do conceito de justificação e que os modelos diferenciadores mais difundidos são insatisfatórios. Além disso, 0 texto defende que as construções doutrinárias usuais traçam limites excessivamente amplos para 0 estado de necessidade. Sugere a adoção de um modelo diferenciador baseado na redução do âmbito de aplicação do art. 24 do CP, aplicando a noção de inexigibilidade como princípio regulativo proposta por Henkel, e na complementação do estado de necessidade justificante legal por um estado de necessidade exculpante supralegal. Conclui que tal solução é superior às alternativas disponíveis em doutrina no que se refere ao respeito do texto legal, à conciliação do estado de necessidade com a coação irresistível e à preservação dos próprios conceitos de justificação e exculpação.

Palavras-chave: estado de necessidade; teoria unitária; teoria diferenciadora; inexigibilidade como princípio regulativo.

Abstract: The article analyzes the problems of the unitary theory and the differentiating models used to explain the scope of art. 24 of the brazilian Penal Code. It seeks to demonstrate that the unitary theory apparently adopted by the law entails a distortion of the concept of justification, and that the most widespread differentiating models are unsatisfactory. Furthermore, the text argues that the usual doctrinal constructions draw excessively broad limits to the necessity defense. It suggests the adoption of a differentiating model based on reducing the scope of application of art. 24 of the brazilian Penal Code, applying the notion proposed by Henkel of unreasonableness as a regulatory principle, and complementing the necessity defense as justification by a supralegal necessity defense as an excuse. It concludes that such a solution is superior to former explanations with regard to respecting the legal text, reconciling the state of necessity with irresistible coercion and preserving the concepts of justification and excuse.

QUANDT, Gustavo de Oliveira. O estado de necessidade no Código Penal brasileiro: uma proposta de modelo diferenciador. Revista do Instituto de Ciências Penais, Belo Horizonte, v. 6, n. 2, p. 438-481, 2021. 
Keywords: necessity defense; unitary theory; differentiating theory; unreasonableness as a regulatory principle.

Sumário: Introdução; 1 A fórmula de 1940 e a teoria unitária justificante; 2 Modelos diferenciadores; 2.1 A teoria diferenciadora divisora do artigo 24; 2.2 A teoria diferenciadora complementadora do artigo 24; 3 A pureza da teoria unitária no Brasil e a coação moral irresistível; 4 0s limites do EN no Brasil; 4.10 EN legal (artigo 24) e 0 auxílio necessário; 4.2 0 EN legal (artigo 24) e 0 conflito entre bens iguais não personalíssimos; 50 significado da preferência do legislador pela teoria unitária; 6 Esforço de solução: 0 desenvolvimento do conceito de (in)exigibilidade referido à justificação e à exculpação; 6.1 Inexigibilidade referida à justificação; 6.1 .1 A posição da provocação prévia do perigo e do dever de enfrentá-lo; 6.2 Inexigibilidade referida à exculpação; Considerações finais; Referências.

\section{Introdução}

Passados mais de 80 anos de sua entrada em vigor, o art. 24 do Código Penal ${ }^{1}$, dedicado ao estado de necessidade (doravante, EN), permanece objeto de controvérsia quanto à natureza jurídica e ao alcance do instituto ali previsto: coexistem em doutrina o modelo unitário justificante e pelo menos duas "teorias diferenciadoras", com pouca ênfase nas diferenças de pressupostos e implicações de cada um desses modelos. Essa multiplicação de explicações, de fato, não nos parece sensível ao problema prático de definir, por exemplo, até onde vai o EN no Direito Penal comum brasileiro, isto é, quais os limites da impunidade assegurada àquele que sacrifica um bem para salvar outro.

O presente texto não pretende expor e resolver todos os problemas do estado de necessidade, objeto de literatura descrita há décadas como "inabarcável"2. Ele volta-se apenas a indicar concisamente os problemas da teoria unitária justificante e da leitura da cláusula da "inexigibilidade do sacrifício" feita pela doutrina brasileira dominante, e a esboçar uma proposta de compatibilização do texto do art. 24 do CP com uma teoria diferenciadora concebida nos moldes do CPM, do $\mathrm{CP}$ alemão e do CP português. Os pormenores da teoria diferenciadora com o perfil proposto estão detalhadamente descritos nas obras europeias de referência citadas ao longo do trabalho. Exemplificativamente, o próprio conceito de perigo, central no EN, será dado por pressuposto ${ }^{3}$.

1 Os dispositivos legais citados sem indicação diversa integram o Código Penal brasileiro em vigor. Os grifos e destaques em transcrições de textos legais são nossos.

3 Outro tema que não abordaremos é o estado de necessidade do Direito Civil, uma vez que, ao contrário do que ocorre na Alemanha - onde os dispositivos da lei civil relativos ao EN contribuem para a fixação dos contornos gerais do instituto -, os trechos do Código Civil brasileiro pertinentes (art. 188, II e parágrafo único, e arts. 929 e 930) são tão indeterminados quanto o art. 24 do CP: dizer-se que "o ato será legítimo somente quando as circunstâncias o tornarem absolutamente necessário" (CC, art. 188, parágrafo único) não acrescenta muito à 


\section{A fórmula de 1940 e a teoria unitária justificante}

Quando o atual Código Penal foi editado, vigorava o CP/1890, que, empregando o mesmo critério do CP/1830, admitia ações em estado de necessidade apenas quando elas fossem praticadas "para evitar mal maior" (CP/1830, art. 14, 1丷ㅜ $\mathrm{CP} / 1890$, art. $\left.32, \S 1^{\circ}\right)^{4}$. Tal solução foi criticada em doutrina porque excluía do alcance da eximente o "caso típico" do estado de necessidade - qual seja, o da "tabula unius capax" ${ }^{5}$, em que dois náufragos disputam o único objeto flutuante disponível, suficiente para salvar apenas um deles ${ }^{6}$.

Abandonando tal critério, o CP/1940 disciplinou o estado de necessidade em um dispositivo flexível, que não se referia à comparação direta entre o mal evitado e o causado, abolindo aquele limite expresso dos Códigos anteriores e tachado de "anti-humano" na Exposição de Motivos7. O dispositivo em questão (art. 20) era precedido pela enumeração expressa do estado de necessidade sob a rubrica "exclusão da criminalidade" (art. 19) - expressão acolhida pelos comentadores como indicativa da exclusão da antijuridicidade ou ilicitude.

Dessas considerações, é possível inferir três pretensões claras do legislador de 1940: (1) adotar a teoria unitária justificante; (2) transigir, ao menos em casos extremos, com a salvação de um bem à custa de outro de igual valor; (3) evitar a simples comparação de bens na definição dos limites do estado de necessidade ${ }^{8}$.

compreensão do que é "razoável exigir-se" (CP, art. 24). Sobre as disposições do CC sobre o EN, v., entre os penalistas, TOLEDO, Princípios básicos de direito penal, p. 188; GALVÃO, Direito penal, p. 442.

Tal critério é geralmente creditado a Bentham: SIQUEIRA, Direito penal brazileiro I, p. 436; BATISTA, LH-Reale Júnior, p. 509; ZAFFARONI/BATISTA/SLOKAR/ALAGIA, Direito penal brasileiro II, II, p. 109.

5 Para um breve histórico da "tabula unius capax" ou "tábua de Carnéades", v. EISELE, Direito penal, p. 505, nota 693; MINORELLI/CEOLIN, REC 72, p. 147-170. 0 caso da "tabula unius capax" admite algumas variantes: em particular, as soluções podem divertir conforme ambos os náufragos tenham chegado simultânea ou sucessivamente à tábua. V., p. ex., MIR PUIG, Derecho Penal, lição 17, n. 68, p. 470.

6 COSTA E SILVA, Código Penal dos Estados Unidos do Brasil commentado I, p. 248. Em idêntico sentido (mas referindo genericamente ao conflito de vida contra vida, sem mencionar o caso da "tabula"), PEREIRA, Tratado de Direito Penal allemão I, p. 236, nota b ("e fica assim fora do estado de extrema necessidade o caso típico, de todos o mais imperioso"). Exporemos nossas ressalvas à expressão "caso típico", utilizada por ambos os mestres citados, na nota 69.

$7 \quad$ Item 17: "No tocante ao estado de necessidade, é igualmente abolido o critério anti-humano com que o direito atual Ihe traça os limites. Não se exige que o direito sacrificado seja inferior ao direito posto a salvo, nem tampouco se reclama a 'falta absoluta de outro meio menos prejudicial'" (grifos do original). Texto transcrito conforme a reprodução em MIRABETE, Código Penal interpretado, p. 48.

8 Os comentadores do Código costumam usar indistintamente os termos "bem" e "interesse" ao tratar do estado de necessidade: v., p. ex., o excerto de Hungria transcrito na nota 67 adiante. Como se verá no item 6.1, o texto abraça a distinção - fundamental, no estudo do EN - entre comparação de bens e ponderação de interesses. Até lá, o termo "interesses" aparecerá apenas em citações. 
Quanto à primeira pretensão, ainda que se queira pôr em dúvida a intenção do legislador de 1940, cremos ser indiscutível que, ao repetir em 1984 a sistemática da Parte Geral original - mesmo após a adoção da teoria diferenciadora no Anteprojeto Hungria (arts. 22 e 26), no decorrente CP/1969 (arts. 25 e 28) e no vigente CPM de 1969 (arts. 39 e 43) -, o legislador que editou a atual Parte Geral decididamente tomou partido da teoria unitária justificante. A mudança da rubrica do art. 23 (equivalente ao antigo art. 19) para "exclusão de ilicitude" tornou ainda mais clara essa opção, ao indicar explicitamente qual requisito da criminalidade é elidido pelo estado de necessidade. Por essa teoria unitária, o estado de necessidade seria sempre justificante.

No entanto, a adoção pela lei de determinado critério não elimina automaticamente as dificuldades denunciadas pela doutrina no seu manejo, perceptíveis desde logo no caso da "tabula unius capax" referido por Costa e Silva em sua crítica à lei anterior ${ }^{9}$. Caso se admita que o náufrago Jack age justificadamente ao tomar de Rose a única tábua (ou porta) flutuante disponível, Rose não poderá repelir a atuação em legítima defesa, pois Jack não pratica agressão injusta ${ }^{10}$. A fim de que a aplicação do critério da inexigibilidade do sacrifício da vida de Jack não resolva o conflito de forma unilateral em favor dele ${ }^{11}$, a solução é estender a Rose idêntica autorização a lutar pela tábua, com o que se abrem as portas para o "estado de necessidade justificante versus estado de necessidade justificante"12, aceito sem grandes questionamentos pela maioria da doutrina nacional ${ }^{13}$. Essa aceitação dos "estados de necessidade justificantes recíprocos" ou contrapostos implica, porém, que a causa de justificação do estado de necessidade não outorga um direito oponível à vítima da ação salvadora: tolera-se que o náufrago procure remover o outro da tábua, mas o primeiro não pode reivindicar a submissão do segundo à sua conduta. Com isso, a ordem jurídica se abstém de dar uma solução a um conflito que envolve bens jurídicos fundamentais e a prática de atos

Cf. nota 6. Associando a impunidade dos náufragos sob o CP/1940 ao abandono da fórmula do "mal maior" do CP/1890, BRUNO, Direito penal I, p. 397; NORONHA, Direito penal PG, p. 232.

10 MARQUES, Tratado de direito penal II, § 68, 8, p. 132 (ainda que fora do contexto de vida contra vida); CEREZO MIR, Derecho Penal PG (Obras completas, t. I), p. 679.

11 Cf. a crítica de GLEIZER, Direito penal PG, § 55, n. 145, p.168.

12 Como apontam criticamente Zaffaroni e Pierangeli, "em princípio, admitir que todo e qualquer estado de necessidade é justificante leva à aceitação, como consequência inafastável, de que no exemplo tão repetido dos náufragos que lutam pela posse da tábua que somente pode manter um deles flutuando, ambos atuam justificadamente" (ZAFFARONI/PIERANGELI, Manual de direito penal brasileiro PG, p. 512).

13 BRUNO, ob. cit. (nota 9), p. 393; NORONHA, ob. cit. (nota 9), n. 115, p. 229; MARQUES, ob. cit. (nota 10), $\S 68,8$, p. 131; MIRABETE, Manual de direito penal I, p. 180; JESUS, Direito penal PG, p. 429 e 439; BITENCOURT, Tratado de direito penal PG, cap. XXI, itens 5 e 5.1. V. ainda as referências adicionais na nota 15. 
definidos como crime, reconhecendo indiscriminadamente o status de justificada às condutas contrapostas, o que Cuello Contreras chamou de "um fracasso do ordenamento jurídico em sua função de pacificação"14. Além disso, transforma-se indevidamente a suposta irrelevância da identidade do náufrago a salvar-se ${ }^{15} \mathrm{em}$ indiferença quanto aos meios e expedientes empregados para a definição do sobrevivente, o que é algo totalmente diverso. Bem vistas as coisas, a teoria unitária justificante preferida pelo legislador é unitária apenas em aparência, pois encobre a distinção entre fatos plenamente justificados (isto é, ações que constituem a solução adequada e definitiva para o conflito, a qual deve ser aceita pela comunidade em geral, e especialmente pelos demais implicados, impondo-lhes o chamado dever de suportarit) e fatos meramente tolerados (que não são ilícitos, ou "penalmente ilícitos", mas não impõem aos demais aquele dever de suportar) ${ }^{17}$.

A doutrina nacional não costuma dar maior atenção aos expedientes teóricos utilizados para explicar essa exclusão da ilicitude que não corresponde à plena justificação do fato $^{18}$, limitando-se a admitir placidamente a ideia de que dois ou mais contendores possam simultaneamente beneficiar-se da exclusão da ilicitude pelo estado de necessidade. A Nélson Hungria, porém, não faltou a percepção dessa diferença qualitativa entre uma justificação que se impõe a todos e

14 CUELLO CONTRERAS, Derecho Penal PG I, cap. X, n. 162, p. 845; v. também cap. X, n. 169, p. 862. Contra a possibilidade de invocar-se o estado de necessidade justificante perante um comportamento justificado, $\mathrm{HIRSCH}$, La posición de la justificación y de la exculpación em la teoría del delito desde la perspectiva alemana, p. 13, nota 6; CEREZO MIR, ob. cit. (nota 10), p. 680; LEITE, Liberdades, n. especial (reforma do Código Penal), p. 83 e 93 ("desafio à lógica deôntica"); ZAFFARONI/PIERANGELI, ob. cit. (nota 12), n. 383, p. 564.

15 Argumento utilizado por NUCCI, Curso de direito penal PG, cap. XXII, item 4.2.1 ("o direito jamais poderá optar entre a vida de um ou de outro"); TOLEDO, ob. cit. (nota 3), n. 169, p. 182; LUZÓN PEÑA, Lecciones de Derecho penal PG, cap. 24, n. 4 (se bem que em combinação com outros fundamentos). V. também NORONHA, ob. cit. (nota 9), n. 115, p. 229; MARQUES, ob. cit. (nota 10), § 68, 1, p. 134.

16 Sobre o dever de suportar, com referências, HILGENDORF/VALERIUS, ob. cit. (nota 11), § 5, n. 8, p. 124; WESSELS/BEULKE/SATZGER, Derecho Penal PG, n. 389, p. 167. Como ponderou Leite, "a declaração de que uma conduta é justa, conforme ao direito, possui conteúdo geral, e não se dirige apenas aos envolvidos" (LEITE, ob. cit. [nota 14], p. 78); v. também HIRSCH, ob. cit. (nota 14), p. 13, nota 6.

17 Em um certo sentido, essa heterogeneidade foi sentida por Basileu Garcia, ao distinguir o fundamento do EN conforme os bens em conflito fossem iguais ou não (GARCIA, Instituições de direito penal I, I, n. 99, p. 331).

18 Merecem menção o "espaço livre de Direito", defendido por Arthur Kaufmann (KAUFMANN, Filosofia do direito, p. 337 e ss.) e convincentemente refutado por Hirsch (HIRSCH, Derecho penal I, p. 89-119), e a teoria da exclusão da ilicitude estritamente penal de H.-L. Günther, que pouca acolhida teve. Cf. HIRSCH, ob. cit. (nota 14), p. 21; ROXIN, Sistema del hecho punible/2, p. 607; CEREZO MIR, ob. cit. (nota 10), p. 589, 592 e 681; DIAS, Direito penal PG, $14^{\circ}$ capítulo, § 10, p. 389). Cirino dos Santos menciona muito vagamente a ideia de "áreas livres do direito", admitidas em "estudos recentes" que o referido autor não nomina (SANTOS, Direito penal PG, p. 258). Batista, por fim, limita-se a dizer que a proibição dirigida ao náufrago que disputasse a "tabula unius capax" seria "irracional e materialmente injusta" (BATISTA, ob. cit. [nota 4], p. 512; ZAFFARONI/BATISTA/SLOKAR/ALAGIA, ob. cit. [nota 4], p. 113). 
a simples tolerância da ordem jurídica em relação a uma conduta típica; procurou contornar a questão afirmando que o estado de necessidade confere uma simples faculdade, e não um autêntico direito ${ }^{19}$. A convenção semântica proposta, contudo, não esconde a pobreza do conceito manejado de causa de justificação, que exclui a pena, mas não dá uma solução conclusiva para o conflito intersubjetivo; como corretamente denunciou Leite, tratava-se de "mudança terminológica que não atingia o cerne do problema" ${ }^{20}$.

De toda forma, o reconhecimento pacífico (e, ao que nos consta, jamais criticado de lege ferenda) de que a lei deixou impune aquele que salva sua vida à custa da vida alheia - tal reconhecimento ainda diz muito pouco sobre o limite máximo do estado de necessidade. Alguns comentadores da PG original, procurando confinar-se nos domínios da ideia de inexigibilidade - com sua evidente tendência a priorizar os dilemas da vítima do perigo originário, em detrimento da vítima da ação típica voltada a debelar aquele perigo -, evitaram comparar os bens em conflito, dando preferência a fórmulas vagas. Costa e Silva, por exemplo, relegou a questão ao caso concreto e ao "prudente arbítrio do juiz", sem, contudo, precisar em quais aspectos concretos o juiz deveria basear seu arbítrio $^{21}$. Bruno chegou a insinuar a equivalência dos bens como limite, mas se manteve firme na rejeição do "fundamento do princípio da avaliação comparativa dos bens", exigindo apenas "certa proporcionalidade entre a gravidade do perigo, atendendo-se ao valor ameaçado, e a lesão produzida no ataque ao bem alheio"22, proporcionalidade que não corresponde exatamente à "proporcionalidade entre o bem ameaçado e o bem agredido", dispensada pelo autor em outra passagem ${ }^{23}$. Igualmente evitando estabelecer limites taxativos, alguns autores enfatizaram os casos de grande desproporção: Marques se referiu à lição de Logoz quanto à impossibilidade de se "matar outrem para a salvaguarda de objeto de

19 HUNGRIA, Comentários ao Código Penal I, II, n. 92, p. 272. Seguiu-o NORONHA, ob. cit. (nota 9), n. 115, p. 229. Em termos muito semelhantes no Direito espanhol, CUERDA RIEZU, La colisión de deberes en derecho penal, p. 311. Na verdade, Hungria era avesso ao dever de suportar, negando-o também na legítima defesa, que por isso mesmo ia igualmente descrita como faculdade e não direito (op. cit., n. 93, p. 285). Mas é no EN que essa contraposição desempenha papel relevante na exposição de Hungria, na medida em que possibilita os EN recíprocos.

20 LEITE, ob. cit. (nota 14), p. 83, nota 103. Os motivos da formulação de Hungria não foram compreendidos por Jesus e Mirabete, que a deslocaram do litígio entre autor e vítima da ação salvadora para o campo do conflito entre agente e Estado, e concluíam que o estado de necessidade confere, sim, um direito (JESUS, ob. cit. [nota 13], p. 411; MIRABETE, ob. cit. [nota 13], n. 4.2.1, p. 177). Com isso, permanece intocado o problema que Hungria habilmente tentou contornar.

21 COSTA E SILVA, Comentários ao Código Penal brasileiro, p. 128.

22 BRUNO, ob. cit. (nota 9), p. 397 e 398.

23 BRUNO, Direito penal IV, p. 93. 
pequeno valor" 24 , e Noronha postulou que o capitão do navio poderia lançar ao mar as mercadorias para salvar os tripulantes, mas não o contrário ${ }^{25}$.

No entanto, em que pese o emprego, na lei, da fórmula flexível da inexigibilidade, a doutrina dominante não se absteve de apelar à comparação entre os bens envolvidos como critério para a determinação do âmbito de incidência do antigo art. 20 e do atual art. 24. Assim é que Hungria, ao louvar a substituição do critério rígido do CP/1890 pela fórmula mais elástica atualmente vigente, reconheceu que "a razoável inexigibilidade [...] não pode prescindir de um cotejo ponderativo entre os bens ou interesses em conflito", concluindo que "a descriminante só deixará de existir se o bem ou interesse posto a salvo, em comparação com o que foi sacrificado, representa, manifestamente, um minus ${ }^{\prime 26}$. Reale Júnior foi mais claro ao caracterizar como simples corretivo o critério da ponderação de bens, na ação praticada em proveito próprio ou de parente, exigindo apenas "certa proporcionalidade" (ou inexistência de "manifesta desproporcionalidade") na comparação entre o mal evitado e o decorrente da ação salvadora ${ }^{27}$.

A doutrina dominante, porém, não foi tão longe e encontrou na equivalência de bens o limite máximo para a justificação ${ }^{28}$. Contudo, caso adotado o

24 MARQUES, ob. cit. (nota 10), § 68, 7, p. 130.

25 NORONHA, ob. cit. (nota 9), n. 116, p. 232. V. também JIMÉNEZ DE ASÚA, Principios de Derecho penal, p. 312.

26 HUNGRIA, ob. cit. (nota 19), n. 92, p. 278. Infelizmente, a ambiguidade do termo "manifestamente" dificulta a compreensão dessa passagem, pois ele tanto pode significar "indiscutivelmente" como "acentuadamente". 0 segundo conceito implica o primeiro: se a diferença é acentuada, torna-se visível e inquestionável. Já a recíproca não é verdadeira: todos sabem que 1.001 é maior que 1.000, embora a diferença seja insignificante (exemplo de COUSIÑO MAC IVER, Derecho penal chileno II, p. 399, com argumentação parcialmente coincidente). Ainda sobre esse problema, v. a nota 93 adiante.

27 REALE JÚNIOR, Instituições de Direito Penal I, p. 168. Também Jesus admitiu o sacrifício de bem superior ao salvo, "desde que esteja presente o requisito da proporcionalidade" (JESUS, ob. cit. [nota 13], p. 422). Com isso, o EN agressivo assume contornos semelhantes aos da legítima defesa, para a qual relevante setor doutrinário requer a inexistência de manifesta desproporcionalidade entre a agressão e a repulsa (v., p. ex., TOLEDO, ob. cit. [nota 3], n. 202, p. 203; FRAGOSO, Direito penal PG, n. 164, p. 193; PERRON, Cuadernos de doctrina y jurisprudencia penal 3, p. 197), e para a qual Reale Júnior exige apenas "alguma proporcionalidade" (ob. cit., p. 158). Com isso, o terceiro sem responsabilidade pelo perigo é colocado em situação semelhante à do autor de uma agressão injusta, o que é inaceitável. No fundo, Reale Júnior e Jesus tentam conciliar a preferência do legislador pela teoria unitária com a possível abrangência da teoria diferenciadora (cf. itens 2.1 e 2.2, infra), reputando justificados aqueles fatos que, nesta última, estariam meramente exculpados. Nucci também interpreta a lei vigente como instituidora de um EN justificante com abrangência própria da teoria diferenciadora, mas admite que não foi esse o caminho seguido por doutrina e jurisprudência e se rende à teoria diferenciadora (NUCCI, ob. cit. [nota 15], cap. XXII, item 4.2.1).

28 Entre os defensores da teoria unitária justificante: GARCIA, ob. cit. (nota 17), n. 97, p. 324; MIRABETE, ob. cit. (nota 13), n. 4.2.2, p. 179; EISELE, ob. cit. (nota 5), p. 504, 506 e 508 (incluindo a não superioridade do bem sacrificado no próprio conceito de EN). Entre os adeptos da teoria diferenciadora: TOLEDO, ob. cit. (nota 3), n. 170, p. 184; BATISTA, ob. cit. (nota 4), p. 512; ZAFFARONI/BATISTA/SLOKAR/ALAGIA, ob. cit. (nota 4), p. 112 (e também p. 121, mais adiante); BITENCOURT, ob. cit. (nota 13), cap. XXI, itens 5.1 e 5.2.5; NUCCI, ob. cit. (nota 15), cap. XXII, item 4.3.5. 
critério unitário justificante para o EN, o reconhecimento do limite da equivalência implica a impossibilidade de isentar de pena o sujeito que, para não sofrer gravíssima mutilação, provoca a morte de outrem ${ }^{29}$.

\section{Modelos diferenciadores}

\subsection{A teoria diferenciadora divisora do artigo 24}

É bem provável que os problemas indicados no tópico anterior - nomeadamente: deformação do conceito de justificação no conflito de bens iguais e dificuldade de sustentar a impunidade de quem provoca mal maior que o evitado - tenham sido a motivação de Fragoso ao adotar, mesmo de lege lata, a teoria diferenciadora. Esse autor postula que o art. 24 esgota o tratamento do EN, mas divide seu campo de incidência em duas hipóteses: quando o bem salvo é superior ao sacrificado, o EN é justificante; se equivalente ou mesmo inferior, é exculpante ${ }^{30}$. Não haveria o reconhecimento de um EN exculpante supralega ${ }^{31}$, mas apenas o desdobramento da natureza jurídica do EN legalmente previsto em justificação e exculpação, conforme o caso ${ }^{32}$.

Essa proposta de Fragoso - também adotada, em suas linhas gerais, por Souza e Zaffaroni/Pierangeli ${ }^{33}$ - sofreu de vários autores a crítica de contrariar a classificação expressamente dada pela rubrica do art. 23 ao EN previsto no

29 Exemplo de SOUSA, Estado de necessidade, p. 9.

30 FRAGOSO, Comentários ao Código Penal I, II, n. 63, p. 590; FRAGOSO, ob. cit. (nota 27), n. 167, p. 197, e n. 202, p. 219.

31 Até porque Fragoso rejeitava a inexigibilidade de conduta diversa como fundamento supralegal de exculpação (FRAGOSO, ob. cit. [nota 30], n. 63, p. 592; FRAGOSO, ob. cit. [nota 27], n. 200, p. 218).

32 FRAGOSO, ob. cit. [nota 27], n. 202, p. 219. V. também n. 200, p. 218.

33 SOUSA, ob. cit. (nota 29), p. 239; ZAFFARONI/PIERANGELI, ob. cit. (nota 12), n. 382, p. 563. Dizemos “em suas linhas gerais" porque não necessariamente coincidem as propostas quanto ao ponto de separação entre justificação e exculpação, e quanto aos limites exteriores do EN exculpante. De fato, é bastante comum (e não só no Brasil) caracterizar-se a teoria diferenciadora dizendo-se que, nela, o EN justificante vale para o conflito de bens desiguais e o exculpante para o de bens iguais (v., p. ex., MIRABETE, ob. cit. [nota 13], n. 4.2.2, p. 179, nota 2; SANTOS, ob. cit. [nota 18], p. 254; SAINZ-CANTERO CAPARRÓS, Comentarios al Código Penal II, p. 347; BARJA DE QUIROGA, Tratado de Derecho Penal PG, p. 654 e 659). Contudo, esse esboço ("muy extendido en el mundo hispanoparlante de diferenciación de ambos que es completamente errado", segundo WILENMANN, Revista de Derecho (Valdivia) 27, p. 217) ignora propostas diferenciadoras legalmente previstas que situam em outro ponto a separação entre justificação e exculpação, tais como a do CPM brasileiro, que exige, para a justificação, a considerável superioridade do bem salvo. A pluralidade de soluções diferenciadoras é denunciada concretamente por Cerezo: "La teoría española de la diferenciación, sobre la naturaleza jurídica del estado de necesidad, no coincide con la teoría alemana del mismo nombre" (CEREZO MIR, ob. cit. [nota 10], p. 677, nota 65); no mesmo sentido, LUZÓN PEÑA, ob. cit. [nota 15], cap. 24, n. 5. 
art. $24^{34}$, e de maneira prejudicial ao réu. Como pondera Busato, "se os requisitos do art. 24 estão presentes em ambos os casos [justificação e exculpação], em nenhum deles é razoável exigir-se o sacrifício do bem posto em perigo, pelo que o autor sempre poderia pretender para si a justificação - mais favorável e ampla, com alcance em outros ramos do direito, do que a exculpação" ${ }^{\prime \prime 3}$.

Por fim, no que interessa à presente abordagem, Fragoso não deu maiores detalhes sobre os limites do estado de necessidade exculpante por ele identificado na disciplina do art. 24: o apelo à exculpação lhe permitiu ir além da equivalência entre o mal evitado e o causado, mas nenhuma outra barreira foi proposta, senão a cláusula geral da inexigibilidade ${ }^{36}$.

\subsection{A teoria diferenciadora complementadora do artigo 24}

Relutantes de afirmar a justificação da conduta que ofende um bem mais valioso do que o preservado, mas desejosos de admitir, ao menos em certos casos, a isenção de pena, alguns autores recorreram à ideia de inexigibilidade de conduta diversa como causa supralegal de exclusão da culpabilidade. Pretenderam, com isso, respeitar a disciplina legal do EN justificante e, ainda assim, atingir resultados justos em situações-limite ${ }^{37}$.

Essa iniciativa enseja, de imediato, duas considerações. A primeira é que, ao reconhecer, ao lado do EN justificante previsto em lei, uma causa supralegal

34 É incorreta, portanto, a afirmação de Zaffaroni e Pierangeli de que a lei brasileira não diz expressamente que o estado de necessidade dos arts. 23, I, e 24, é uma causa de justificação (ZAFFARONI/PIERANGELI, ob. cit. [nota 12], n. 339, p. 513).

35 BUSATO, Direito penal PG, p. 485. Em sentido semelhante, SANTOS, ob. cit. (nota 18), p. 262; BITENCOURT, ob. cit. (nota 13), cap. XXI, item 5.1; BATISTA, ob. cit. (nota 4), p. 513; TOLEDO, ob. cit. (nota 3), n. 167, p. 180. Outra possível crítica, que surge nos debates sobre o art. 20, 5, do CP espanhol, e que foi antecipada por Souza no Brasil, é relativa à cisão da natureza jurídica de um instituto previsto de forma unitária na lei (SOUSA, ob. cit. [nota 29], p. 239).

36 FRAGOSO, ob. cit. (nota 27), n. 202, p. 219. Além disso, em passagens pouco claras, Fragoso parecia aceitar estados de necessidade justificantes recíprocos: FRAGOSO, ob. cit. (nota 30), n. 63, p. 591; FRAGOSO, ob. cit. (nota 27), n. 168, p. 197. Contudo, em um sistema em que a justificação exige a superioridade do bem salvo, como propunha Fragoso, essa reciprocidade sequer é concebível, pois não há como dois bens serem simultaneamente superiores um ao outro.

37 TOLEDO, ob. cit. (nota 3), n. 167, p. 181; BITENCOURT, ob. cit. (nota 13), cap. XXI, itens 5.1 e 5.2.5; NUCCI, ob. cit. (nota 15), cap. XXII, itens 4.2.1 e 4.3.5. Um ponto de encontro da solução analisada no item 2.1 com a exposta no presente tópico é a formulação de Zaffaroni/Batista, que abraçam o critério diferenciador, subsomem ambas as modalidades de EN no art. 24, mas reconhecem a justificação no conflito de bens iguais (ZAFFARONI/ BATISTA/SLOKAR/ALAGIA, ob. cit. [nota 4], p. 112 e 355). Com isso, Zaffaroni/Batista atraem simultaneamente as críticas merecidas por cada uma das propostas diferenciadoras descritas no texto. Por outro lado, esses autores detêm o mérito de haverem procurado explicar a duplicação da inexigibilidade denunciada adiante (cf. nota 44, infra). 
de exclusão da culpabilidade caracterizada pela necessidade de salvar, à custa de outro, um bem jurídico exposto a perigo atual e inevitável, esses autores procederam ao abandono da teoria unitária e à indiscutível adoção da teoria diferenciadora, pois uma causa de exculpação com essas características é, sem tirar nem pôr, o estado de necessidade exculpante. Consequentemente, uma solução que complementa um EN justificante com um EN exculpante é inequivocamente uma solução diferenciadora ${ }^{38}$, independentemente dos nomes que se escolham ${ }^{39}$.

A segunda consideração concerne ao problema da conciliação dessa proposta com a técnica adotada na definição legal do EN justificante. Como dito no item 1, o legislador não caracterizou o EN justificante segundo a ponderação de bens, valendo-se, em vez disso, da ideia de exigibilidade - a qual, no dizer de Batista, compõe "o léxico da culpabilidade" 40 e constitui precisamente a base sobre a qual os autores indicados no início do tópico erguem sua noção de estado de necessidade supralegal ${ }^{41}$. Uma vez que o EN exculpante é subsidiário do EN justificante ${ }^{42}$ (pois a análise da ilicitude precede a da culpabilidade), a afirmação de que uma conduta deve ser isenta de pena em razão da incidência do primeiro pressupõe declarar-se que o sacrifício do bem em cujo favor o sujeito atuou "era razoável exigir-se" (art. 24, a contrario) e que, ainda assim, o agente é exculpado porque não lhe era exigível conduta diversa.

38 Convém registrar que a dicotomia "justificação x exculpação" não esgota as soluções propostas em doutrina para explicar a impunidade da conduta típica praticada em estado de necessidade. Contudo, não nos parece que os conceitos estranhos ao debate nacional, tais como o de responsabilidade pelo fato, devido a Maurach (MAURACH/ZIPF, Derecho Penal PG § 31/1, p. 535), contribuam para resolver os problemas centrais do texto, que são uma noção excessivamente ampla de justificação e a identificação dos limites exteriores do estado de necessidade no Direito Penal comum brasileiro. Por essa razão, restringir-nos-emos à brevíssima menção feita a alguns desses conceitos na nota 18.

39 Segundo nosso critério de identificação da teoria unitária, que não aceita complementos exculpantes sob quaisquer denominações, o seguinte trecho é uma contradição em termos: "Assis Toledo, apesar de filiar-se à teoria unitária, admite o estado de necessidade exculpante quando implicar sacrifício de bem de maior valor, como causa extralegal de exclusão da culpabilidade". PRADO, Tratado de direito penal brasileiro PG, cap. XI, item 2.1.2, texto prévio à nota 53. Além disso, entendemos que Toledo simplesmente repeliu a específica proposta diferenciadora de Fragoso (cf. nota 35, supra), mas reconheceu abertamente que sua própria solução era diferenciadora, inclusive utilizando a expressão "estado de necessidade exculpante". TOLEDO, ob. cit. (nota 3), n. 167 e 168, p. 180-181.

40 BATISTA, ob. cit. (nota 4), p. 512; ZAFFARONI/BATISTA/SLOKAR/ALAGIA, ob. cit. (nota 4), p. 112 e 355.

41 É significativo que Goldschmidt, comentando o dispositivo, bastante semelhante ao art. 24 do CP brasileiro, de um anteprojeto suíço, visse ali uma causa de exculpação, e não de justificação (GOLDSCHMIDT, Derecho, Derecho penal y proceso I, p. 378). V. ainda a citação em HENKEL, Exigibilidad e inexigibilidad como principio jurídico regulativo, p. 49 , nota 7. 
Com isso, cria-se uma duplicação do conceito de exigibilidade que a doutrina majoritária raramente se esforçou para explicar ${ }^{43}$. Sob esse aspecto, a diferença entre o caminho trilhado por Fragoso, Souza e Zaffaroni/Pierangeli (consistente em dividir o campo de aplicação do art. 24 em duas partes) e a alternativa adotada pelos críticos (respeitar a abrangência do art. 24 e complementá-lo com um estado de necessidade exculpante supralegal) é mais aparente do que real, pois ambos reconhecem, apesar da redação do art. 24, a existência de fatos cuja abstenção é inexigível que seriam meramente exculpados ${ }^{44}$. No final das contas, a diferença entre os métodos seguidos se concentra na solução dos casos de conflitos de bens iguais: exculpação, para os que declaradamente fracionam o art. 24, e justificação, para os que dizem apenas complementá-lo ${ }^{45}$.

\section{A pureza da teoria unitária no Brasil e a coação moral irresistível}

À vista do exposto nos tópicos precedentes, parece possível separar as opiniões dos comentadores do $\mathrm{CP}$ em três grandes grupos ${ }^{46}$ : a) os que acatam a preferência do legislador pela teoria unitária e desenvolvem o critério às últimas consequências (item 1); ${ }^{47}$ b) os que acomodam todas as hipóteses de estado de necessidade no art. 24, mas ignoram a preferência do legislador pela solução unitária e desmembram a natureza jurídica do instituto em justificação e exculpação (item 2.1); c) os que aderem à interpretação unitária do art. 24, mas o complementam com um estado de necessidade exculpante supralegal (item 2.2).

43 Essa duplicação, denunciamo-la em QUANDT, Reforma penal, p. 208.

44 Bitencourt insinuou distinguirem-se a razoabilidade do sacrifício (art. 24) e a inexigibilidade (supralegal) de outra conduta (BITENCOURT, ob. cit. [nota 13], cap. XXI, n. 5.1). Contudo, cremos que essa ideia precisaria ser mais detalhada - como tentaremos fazer no item 6 . Antes dele, Souza, que propunha cindir o âmbito de aplicação do art. 20 (atual art. 24) - cf. nota 33, supra - sugeriu a diferença entre inexigibilidade objetiva, referida à justificação, e subjetiva, relativa à exculpação (SOUSA, ob. cit. [nota 29], p. XIII, 233 e 238). Essa contraposição foi repetida por ZAFFARONI/BATISTA/SLOKAR/ALAGIA, ob. cit. (nota 4), p. 125, 350, 355, 359, que páginas antes destacaram o "importante estudo monográfico" de Sousa (ob. cit., p. 111, nota 175).

45 Confrontando brevemente as duas soluções diferenciadoras referidas no texto, GRECO, Curso de direito penal PG, p. 378.

46 Alguns autores são de difícil inserção no esquema proposto no texto - seja por não serem inteiramente claros quanto à forma de adaptação de sua proposta ao texto legal (cf. nota 73, infra), seja por não se manifestarem sobre as hipóteses de salvação de bem inferior à custa do superior. Sobre esse silêncio, v. a observação de Silva Sánchez na nota 139 , infra.

47 Eisele afirma que o CP comum adotou a teoria diferenciadora porque identifica, no art. $24, \S 2^{\circ}$, um EN exculpante (EISELE, ob. cit. [nota 5], p. 510, nota 705; p. 504, nota 692). Contudo, o termo exculpação geralmente se refere à completa impunidade do agente. Assim, a opinião de Eisele coincide com a teoria unitária justificante, ainda que ele mesmo rejeite tal denominação (ob. cit., p. 509, nota 700). 
Já tivemos oportunidade de comentar no item 2.2 que a proposta do grupo "c" é inequivocamente diferenciadora. No presente tópico, desejamos chamar a atenção para o fato de que mesmo os autores que dizem satisfazer-se apenas com o EN justificante têm essa postura facilitada pela opção do legislador de destacar a coação irresistível do estado de necessidade. Como se sabe, a lei brasileira prevê, de modo autônomo, a coação irresistível (art. 22), à qual a doutrina nacional geralmente atribui a natureza de causa de exculpação ${ }^{48}$. Ocorre que essa previsão separada da coação não é imprescindível: no CP alemão vigente, sequer há dispositivo próprio para ela, que se rege integralmente pelos preceitos dedicados ao $\mathrm{EN}^{49}$. De fato, do ponto de vista do agente que executa diretamente o fato previsto como crime, não faz muita diferença se o mal que o assombra advém de uma coação ou de uma catástrofe natural, por exemplo: tanto faz furtar por ordem de alguém que ameaça o filho do coato ${ }^{50}$, como furtar medicamentos para combater moléstia grave que põe em iminente perigo a vida desse mesmo filho.

Uma vez que se abstraia, para a caracterização do EN, a origem do perigo - seja ela violência, grave ameaça ou qualquer outra -, tem-se que a teoria unitária justificante defendida no Brasil tem sua pureza assegurada por uma opção legislativa discutível, qual seja, a retirada da coação excludente da culpabilidade do âmbito do EN.

É verdade que a classificação irrestrita da coação irresistível como causa de exculpação pode ela mesma ser controvertida, havendo um grupo crescente de autores brasileiros para os quais a conduta do coato estará justificada, se preenchidos os pressupostos do EN justificante ${ }^{51}$. Ainda assim, não nos parece que os

48 V., p. ex., BRUNO, Direito penal II, p. 171, nota 1; ANDREUCCI, Coação irresistível por violência, p. 101; PRADO, ob. cit. (nota 39), cap. XII, n. 4.3.1 a.

49 No Brasil, Sousa julgou desnecessária a previsão destacada da coação no CP/1969, especialmente porque este regulava à parte, com maior detalhamento, o EN exculpante (SOUSA, ob. cit. (nota 29), p. 215, 241 e 254). Mais recentemente, Zaffaroni e Pierangeli proclamaram que a coação não tem autonomia doutrinária, embora a tenha "sob a ótica legal" (ZAFFARONI/PIERANGELI, ob. cit. [nota 12], n. 381, p. 562). V. também ZAFFARONI/ BATISTA/SLOKAR/ALAGIA, ob. cit. (nota 4), p. 333. Em defesa do tratamento autônomo da coação irresistível, independentemente da natureza jurídica que se Ihe atribua, LEITE, ob. cit. (nota 14), p. 90.

50 Exemplo de Nucci, adepto da classificação tradicional da coação irresistível como causa de exculpação: o gerente do banco que abre o cofre sob ameaça de morte de sua família, que está em poder de bandidos, pratica fato ilícito, pois "não há excludente de antijuridicidade em seu favor" (NUCCI, ob. cit. [nota 15], cap. XXIII, item 3.2.1.1). Tratando a coação como caso especial de estado de necessidade exculpante, GLEIZER, ob. cit. (nota 11), § 5/145, p. 169.

51 BITENCOURT, ob. cit. (nota 13), cap. XXIV, item 2.1; ZAFFARONI/PIERANGELI, ob. cit. (nota 12), n. 337, p. 511, e n. 383, p. 564; GALVÃO, ob. cit. (nota 3), n. 8.9.4, p. 548; ZAFFARONI/BATISTA/SLOKAR/ALAGIA, ob. cit. (nota 4), p. 113 e 334. V. também a argumentação de SOUSA, ob. cit. (nota 29), p. 79 e 219, nota 50, o qual, contudo, não parece convencer-se do eventual caráter justificante da coação. Ainda assim, é forçoso registrar 
defensores do possível caráter justificante da coação - com os quais concordamos inteiramente - pretendam atribuir essa natureza jurídica a todas as hipóteses do art. 22, o que significa que, sob qualquer ponto de vista, haverá casos de coação meramente exculpante. Uma vez incorporada ao EN a coação moral irresistível, o que se tem é uma teoria diferenciadora - ainda que o critério de distinção entre justificação e exculpação se desloque da comparação entre os bens para a natureza fonte do perigo ${ }^{52}$.

\section{Os limites do EN no Brasil}

Os tópicos anteriores se dedicaram precipuamente aos problemas da coerência interna dos modelos de EN propostos em doutrina. O presente tópico se concentra nos problemas relativos à delimitação do alcance do EN no Direito brasileiro, isto é, à determinação da extensão do universo de condutas que ficariam impunes perante a lei brasileira em razão de terem sido praticadas por necessidade.

\subsection{EN legal (artigo 24) e 0 auxílio necessário}

Como se vê, a maioria dos comentadores brasileiros, ao analisar o caso extremo da "tabula unius capax", aceita a justificação de condutas que, para evitar o sacrifício de um bem, impõem idêntico dano a um bem equivalente (itens 1 e 2.2). No item 1, indicamos os defeitos que essa concepção acarreta para a própria noção de justificação. No presente tópico e no seguinte, apontaremos outros dois problemas relacionados ao denominado "conflito de bens iguais".

O primeiro deles surge quando se considera o auxílio necessário, ou seja, a ação em estado de necessidade voltada a preservar direito de terceiro. A conjugação da ideia de que o art. 24 alcança os conflitos entre bens iguais com a expressa menção legal da possibilidade de atuação em favor de outrem (art. 24: "direito próprio ou alheio") leva inexoravelmente à conclusão de que também deve ficar

que, mesmo na Alemanha, onde, como dito, se adota a teoria diferenciadora e a coação é mera subespécie do EN, diversos autores a inserem sempre no EN exculpante, recusando a possibilidade de justificação: WESSELS/ BEULKE/SATZGER, ob. cit. (nota 16), n. 664a, p. 308; HILGENDORF/VALERIUS, ob. cit. (nota 11), § 6, n. 51, p. 189. V. outras referências em ESER/BURKHARDT, Derecho penal, caso 18, A 6, p. 370. Tratando certas hipóteses de coação como EN justificante, JAKOBS, Derecho penal PG, ap. 13, n. 14, p. 501; STRATENWERTH, Derecho penal PG, § 9, n. 98, p. 246.

52 Bitencourt também alude à coação irresistível para demonstrar que o legislador, embora tenha optado pela teoria unitária do EN, reconheceu a exclusão da culpabilidade por inexigibilidade de outra conduta decorrente do conflito de interesses (BITENCOURT, ob. cit. [nota 13], cap. XXI, item 5.1). 
impune o agente $C$, que, sem relação pessoal com os envolvidos ${ }^{53}$, compromete um bem de A para salvar bem equivalente de $B^{54}$. De fato, em um estado de necessidade verdadeiramente justificante, que apresenta a solução definitiva do conflito intersubjetivo, a ser respeitada por todos, a identidade de quem pratica a conduta é irrelevante ${ }^{55}$, razão pela qual os limites do EN são idênticos para o titular do bem salvo e para terceiros sem relação com os envolvidos: tanto é lícito abater um cão para não ser mordido, como o é para evitar que o cão morda um desconhecido. Contudo, nas situações de conflito de bens iguais, o reconhecimento de que a ação salvadora estaria justificada para o titular do bem ameaçado, e a concomitante outorga a um terceiro das mesmas possibilidades reconhecidas àquele titular, concede a esse terceiro um poder de intervenção que não se explica satisfatoriamente sob nenhum aspecto: Por que se deveria conferir a $C$, que está distante demais de A e B para Ihes jogar uma boia adicional, a possibilidade de alvejar um deles com um fuzil de precisão para que o outro se salve com a única boia próxima de ambos, projetada para suportar apenas uma pessoa? ${ }^{56}$ Como corretamente critica Cerezo, "cualquier persona estaría facultada para intervenir y arrogarse el papel de árbitro" ${ }^{\prime 57}$.

A questão ganha importância quando se abandona o exemplo distante dos náufragos e se considera o setor de emergências de um hospital, insuficiente para atender todas as pessoas que o procuram correndo risco de vida. Se o conflito entre vidas permite escolher entre qualquer delas, então qualquer cidadão C pode remover o paciente que utiliza as máquinas que o mantêm vivo para dar lugar a outro em condições semelhantes. A completa inaptidão de tal modelo para promover a paz social e a segurança jurídica se revela ainda mais quando se multiplicam os terceiros, pois o sujeito D pode não concordar com a escolha de C e tentar impedi-lo violentamente de interferir, dando origem aos "auxílios ne-

53 "A intervenção necessária pode ocorrer para salvar um bem jurídico do sujeito ou de terceiro [...]. No último caso, não se exige qualquer relação jurídica específica entre ambos (não se exige relação de parentesco, amizade ou subordinação entre o agente e o terceiro necessitado)." (JESUS, ob. cit. [nota 13], p. 417)

54 Essa conclusão é defendida abertamente por Gimbernat perante o Direito espanhol (GIMBERNAT ORDEIG, Estudios de Derecho penal, p. 222). V. também nota 131, infra.

55 Mais ou menos nesse sentido, PERRON, ob. cit. (nota 27), p. 203; ESER/BURKHARDT, ob. cit. (nota 51), caso 12, A 57, p. 266; STRATENWERTH, ob. cit. (nota 51), § 12, n. 112, p. 251; CORREIA, Direito criminal II, p. 89; DIAS, ob. cit. (nota 18), cap. $16^{\circ}$, § 31, p. 459; CUELLO CONTRERAS, ob. cit. (nota 14), cap. X, n. 183, p. 862.

56 Exemplo de Zaffaroni e Pierangeli, que igualmente contestam a impunidade do atirador (ZAFFARONI/PIERANGELI, ob. cit. [nota 12], n. 338, p. 513).

57 CEREZO MIR, ob. cit. (nota 10), p. 683, e em termos semelhantes na p. 691. Para a questão no Direito espanhol, v. nota 117, infra. V. também GOLDSCHMIDT, ob. cit. (nota 41), p. 388. 
cessários contrapostos". Custa-nos aceitar que esse bellum omnium contra omnes se ajuste ao texto do art. 24.

Alguns autores invocaram a noção de solidariedade para justificar a dispensa, pelo Código, da exigência de uma relação de proximidade entre o agente que presta o auxílio necessário e o beneficiário da ação típica ${ }^{58}$. No entanto, a aplicação desse argumento aos conflitos de bens iguais revela que o apelo à solidariedade não supre as deficiências explicativas da vaga ideia de inexigibilidade do sacrifício do bem em perigo, sem maiores desenvolvimentos. Em particular, a referência à solidariedade do terceiro interveniente soa pouco feliz no caso dos náufragos: solidariedade que mata um terceiro inocente? ${ }^{59}$

A percepção do impasse não escapou a Reale Júnior, que postulou que, no caso de auxílio necessário proporcionado por terceiro sem relação com a pessoa salva, o bem a ser salvo deveria ser superior ao sacrificado, a fim de evitar que se converta "o terceiro em único juiz de sua própria ação" ${ }^{60}$. Com isso, resolveu os problemas antes denunciados, mas manteve intactos aqueles do conflito de bens iguais quando a ação salvadora é praticada pelo próprio necessitado (item 4.2 , infra), e traiu a premissa de que se trata de verdadeira justificação, pois fez os limites da ação salvadora dependerem da identidade da pessoa que a pratica.

Rogério Greco também constatou que o terceiro que presta o auxílio necessário por vezes termina por "se arvorar em juiz do caso". Contudo, esse autor não associou a questão ao dilema do conflito entre bens equivalentes, vinculando-a à disponibilidade ou indisponibilidade do bem originalmente ameaçado, para concluir que, no exemplo da "tabula unius capax", o terceiro poderia atuar, pois o bem é indisponível; se, pelo contrário, o bem ameaçado for disponível, sua preservação por terceiro estaria vedada, porque "não pode o agente [i.é, o terceiro]

58 BRUNO, ob. cit. (nota 9), p. 396; HUNGRIA, ob. cit. (nota 19), n. 92, p. 275; MARQUES, ob. cit. (nota 10), $\S 68,3$, p. 126.

59 Não se nega que a solidariedade desempenhe algum papel explicativo do EN: v., entre outros, FRANCO, Código Penal e sua interpretação, n. 1.00, p. 203; WESSELS/BEULKE/SATZGER, ob. cit. (nota 16), n. 441, p. 191; BARJA DE QUIROGA, ob. cit. (nota 33), p. 654; SOUSA, ob. cit. (nota 29), p. 105; WILENMANN, ob. cit. (nota 33), p. 234. 0 denso sistema de Baldó para a legítima defesa e o EN justificante (assim compreendido, pelo autor, como o que fundamenta um dever de suportar) se baseia na iteração entre autonomia individual e solidariedade inclusive a solidariedade do terceiro que presta o auxílio necessário, que Baldó relaciona com a norma mandamental subjacente aos crimes de omissão de socorro (BALDÓ LAVILLA, Estado de necesidad y legítima defensa, p. 199 e ss.; v. também JAKOBS, ob. cit. [nota 51], ap. 11, n. 3, p. 421). Mas é evidente - e o sistema proposto por Baldó não desvia disso - que a solidariedade central no EN justificante agressivo é a da pessoa afetada pela ação salvadora, e não do terceiro que presta auxílio necessário!

REALE JÚNIOR, ob. cit. (nota 27), p. 169. 
se arvorar em juiz do caso e decidir pela sua não disponibilidade"61 - a menos que o beneficiário da ação típica prestasse seu consentimento para ela ${ }^{62}$. Que o problema da transformação do terceiro em "juiz do caso" não está na disponibilidade, é algo que decorre do fato de que a vida de ambos os contendores é indisponível; que o problema não está no consentimento decorre do fato de que, em uma situação em que o terceiro detém o poder de fato de escolher qual bem será salvo ${ }^{63}$, os dois envolvidos podem outorgar dito consentimento. Em ambos os casos, o terceiro clamará o poder de escolher o vencedor, convertendo-se no "juiz do caso" que R. Greco corretamente considera inaceitável ${ }^{64}$.

Naturalmente, os argumentos expostos antes não impedem a postulação da impunidade do terceiro interveniente em alguns casos. Contudo, descreditam a ideia de que o terceiro, sem relação próxima com nenhum dos envolvidos e na ausência de outro fator relevante, possa decidir o desfecho de conflitos entre bens

61 GRECO, ob. cit. (nota 45), p. 384.

62 Exigindo o consentimento do beneficiário da ação praticada em auxílio necessário, ESER/BURKHARDT, ob. cit. (nota 51), caso 12, A 43, p. 263; ZAFFARONI/PIERANGELI, ob. cit. (nota 12), n. 342, p. 515; BALDÓ LAVILLA, ob. cit. (nota 59), p. 196; TOLEDO, ob. cit. (nota 3), n. 174, p. 187, seguido por BITENCOURT, ob. cit. (nota 13), cap. XXI, item 5.2.2, e pelo próprio GRECO, ob. cit. (nota 45), op. cit., p. 385. Contra tal exigência, BRUNO, ob. cit. (nota 9), p. 396; NORONHA, ob. cit. (nota 9), n. 116, p. 232; JESUS, ob. cit. (nota 13), p. 417; MARQUES, ob. cit. (nota 10), § 68, 3, p. 126. V. ainda as ponderações de ZAFFARONI/BATISTA/SLOKAR/ALAGIA, ob. cit. (nota 4), p. 116. Outrossim, temos dúvidas de que a exigência do consentimento se relacione à disponibilidade do bem a ser salvo: no conflito entre vidas (bens indisponíveis por excelência), qual o fundamento de se permitir ao terceiro que desconsidere o desejo do náufrago-pai de sacrificar-se em favor do náufrago-filho? Reconhecendo em alguma medida a autonomia de quem prefere sacrificar-se para que outro seja salvo, SOUSA, ob. cit. (nota 29), p. 144. V. também as considerações de JAKOBS, ob. cit. (nota 51), ap. 13, n. 29, p. 511.

63 A ressalva entre vírgulas se deve ao fato de que o exemplo dado por R. Greco para defender a necessidade de consentimento quando o bem a ser salvo é disponível não era de escolha entre dois bens igualmente aptos a serem preservados, mas sim de um incêndio na casa 1, cujo alastramento para a casa 3 é detido mediante a destruição da casa 2. Como se vê, o exemplo não comportava a possibilidade de salvação da casa 2, que será derrubada pelo terceiro ou consumida pelas chamas. No item 6.1 , retomaremos brevemente esses casos em que o bem sacrificado estava irremediavelmente comprometido.

64 Na colisão de deveres, a impossibilidade de atendê-los todos simultaneamente impõe que se aceite a escolha entre deveres equivalentes feita pelo terceiro, cuja conversão em "juiz do caso" é inevitável. Daí porque a doutrina dominante considera o conflito de deveres uma causa de justificação autônoma, não compreendida no conceito de EN, e para a qual basta a equivalência entre os deveres em conflito: está justificada (e não simplesmente exculpada) a omissão do pai de salvar um filho no naufrágio, se esse pai presta socorro a outro filho e não dispõe de meios para salvar ambos. MINORELLI/CAETANO, Direito Público 94, p. 288; HILGENDORF/VALERIUS, ob. cit. (nota 11), § 11/84, p. 348; CORREIA, ob. cit. (nota 55), p. 92; DIAS, ob. cit. (nota 18), cap. 16º § 41, p. 466; PERRON, ob. cit. (nota 27), p. 186; HIRSCH, Derecho penal I, p. 129; HIRSCH, ob. cit. (nota 14), p. 51. Por essa razão é incorreto invocar, como faz Muñoz Conde, exemplos de conflitos de deveres para comprovar que basta a equivalência entre os bens em conflito para justificar o auxílio necessário (BITENCOURT/MUÑOZ CONDE, Teoria geral do delito, p. 254). Crítico da argumentação de Muñoz Conde, CUELLO CONTRERAS, ob. cit. (nota 14), cap. X, n. 163, p. 846, nota 305. 
iguais, o que, por sua vez, põe em dúvida a premissa de que, nesses conflitos, o EN é justificante.

\subsection{EN legal (artigo 24) e o conflito entre bens iguais não personalíssimos}

Quando alguém, em situação de necessidade, salva a própria vida à custa da vida alheia, tem-se um fato cuja impunidade não é discutida, apesar das controvérsias quanto à natureza jurídica da eximente aplicável. No entanto, o acerto material da conclusão pela impunidade se torna menos evidente à medida que se rebaixa a importância dos bens em conflito - isto é, quando esses bens iguais não são personalíssimos (vida, integridade física em relação a danos severos etc.). Aparentemente, alguns autores conjugaram a ideia de que (1) o legislador quis assegurar, ao menos em princípio e em alguns casos, a impunidade de quem pratica uma ação salvadora que provoca estrago equivalente ao que pretendia evitar (cf. item 1, supra), com a máxima de que (2) a lei brasileira não estabeleceu restrições quanto ao bem jurídico a ser salvo no $\mathrm{EN}^{65} \mathrm{e}$, dessas duas premissas mais ou menos corretas ${ }^{66}$, deduziu que, no conflito entre bens iguais, a ação será sempre isenta de pena ${ }^{67}$. Ocorre que essa extrapolação é discutível, não decorre inexoravelmente do texto da lei vigente e constitui um mau fruto do argumento da indiferença, para o Direito, da identidade da pessoa cujo bem afinal se preservou - argumento utilizado no exame do caso da "tabula unius capax" (nota 15, supra).

De fato, se o legislador quisesse deixar impune toda ação que, para evitar o sacrifício de um bem, provocasse malefício equivalente, bastar-lhe-ia adotar fórmula próxima à da lei espanhola, que exige apenas "que el mal causado no sea mayor que el que se trate de evitar" (art. 20, 5). Ao aceitar, em todos os casos, a equivalência dos bens, a doutrina reverteu a substituição operada pelo legislador de 1940 de uma comparação rígida por um dispositivo aberto (item 1), alterando apenas o limite legal - de "evitar mal maior" (solução do CP/1890) para "evitar

Por todos, BRUNO, ob. cit. (nota 9), p. 396.

Como se verá no item 6.1, propomos que se exija um mínimo considerável de gravidade do perigo a ser debelado no estado de necessidade, o que exclui a salvação de bens de escasso valor. Assim, embora o bem jurídico "patrimônio" possa ser salvo em EN, nem todo bem patrimonial conta com essa proteção.

"Entrando em conflito bens ou interesses que merecem igualmente a proteção jurídica, é concedida a faculdade da própria ação violenta para o salvamento de qualquer deles" (HUNGRIA, ob. cit. [nota 21], n. 92, p. 272, citado por TOLEDO, ob. cit. [nota 3], n. 166, p. 180; n. 169, p. 182; n. 175, p. 187; NORONHA, ob. cit. [nota 9], n. 115, p. 228). A glosa de Delmanto e colaboradores ao $\S 2^{\circ}$ do art. 24 também sugere que a igualdade de bens sempre basta: "Caso fosse razoável ao agente sacrificar seu bem ameaçado, em face da maior relevância do direito por ele violado, não haverá exclusão de ilicitude, mas a pena deve ser diminuída de um a dois terços" (DELMANTO et al., Código Penal comentado, nota ao art. 24, $\S 2^{\circ}$ ). Em termos semelhantes, NUCCI, ob. cit. (nota 15), cap. XXII, n. 4.4; MIRABETE, ob. cit. (nota 13), n. 4.2.2, p. 179. 
mal não superior". E o desacerto material da solução é sugerido pelo fato de que alguns autores espanhóis, louvando-se no conteúdo fortemente normativo da palavra "mal", propõem soluções segundo as quais nem todo conflito de bens iguais exime de responsabilidade ${ }^{68}$.

O problema está no fato de que, no conflito entre vidas, existem razões específicas, conhecidas de longa data, a fundamentar a impunidade daquele que se salva à custa do outro, tais como a ineficácia da ameaça penal perante aquele que está prestes a morrer, a preponderância do instinto de sobrevivência sobre a capacidade de se motivar pela norma etc. ${ }^{69}$ Pouco importa, por ora, se essas razões concernem à justificação ou à exculpação; interessa notar, neste tópico, que o poder de convencimento do inexato brocardo "necessitas non habet legem" vai diminuindo à medida que diminui o valor do bem jurídico que se pretende salvar: se A é surpreendido por uma chuva de granizo, e, para proteger sua motocicleta, retira a de $B$, de preço semelhante, da garagem coberta em que ela se encontra e acomoda a sua, o que se tem é antes uma conduta egoísta do que uma conduta que deva permanecer impune; não vemos razão alguma para declarar, nos termos do art. 24, que o sacrifício da motocicleta de A "não era razoável exigir-se"70.

Por fim, é possível combinar as situações expostas no presente item (salvação de bem não personalíssimo mediante sacrifício de bem equivalente) e no item precedente (auxílio necessário): o vizinho C, que simpatiza com A mas detesta B,

68 V. muito especialmente Mir Puig, em cuja construção nos inspiramos abertamente no item 6, infra (MIR PUIG, ob. cit. [nota 5], lição 17, n. 27, p. 458, e n. 29, p. 459). Também Luzón, embora defenda a teoria unitária e aceite a justificação no conflito entre males iguais (LUZÓN PEÑA, ob. cit. [nota 15], cap. 24, n. 8), ressalva que, se o perigo atingia um bem e é desviado para outro bem equivalente que estava a salvo, não existe equivalência de males (ob. cit., cap. 24, n. 40). Conclusão semelhante, mas não exatamente nos mesmos termos, em OCTAVIO DE TOLEDO Y UBIETO/HUERTA TOCILDO, Derecho Penal PG, p. 235 e 238.

69 Bruno, adepto da teoria unitária justificante, explica-a considerando que o "instinto de conservação" torna 0 "comando da lei, impossível de ser cumprido"; seria "vão que a lei viesse impor que o agente, sob a pressão do mal visível e urgente [...], se quedasse inativo enquanto perdesse o bem ameaçado". Conclui que "não se pode impor como dever jurídico uma atitude de renúncia que muitas vezes precisaria tornar-se heroica" (BRUNO, ob. cit. [nota 9], p. 394). Muito próximo a Bruno, mas sem aludir a ele, BITENCOURT, ob. cit. [nota 13], cap. XXI, item 5. Observa-se que esses fundamentos, sonoros para o caso da "tabula unius capax", perdem seu apelo à medida que se rebaixa o valor dos bens idênticos envolvidos: conforme observa Silva, a explicação do EN baseada no instinto de conservação "certamente só tem plena validade a respeito de certos casos extremos" (SILVA SÁNCHEZ, Consideraciones sobre la teoría del delito, p. 229). Daí nossas ressalvas quanto à conveniência de se proclamar a "tabula unius capax" como o caso típico do estado de necessidade (cf. nota 6): é, sim, um caso emblemático e representativo de seus mais dramáticos contornos - mas não um caso cuja solução assegure, desde logo, a elucidação do problema todo. Cuello Contreras indica como "supuesto estándar" do EN um sacrifício patrimonial em benefício da vida (CUELLO CONTRERAS, ob. cit. [nota 14], cap. X, n. 194, p. 867). Quando muito, o caso da tábua é representativo do EN exculpante (cf. nota 124, infra).

70 Exemplo adaptado de ZAFFARONI/PIERANGELI, ob. cit. (nota 12), n. 382, p. 563, que igualmente concluem que a conduta não atende à exigência do art. 24 de inexigibilidade do sacrifício. 
retira a motocicleta deste da garagem em que se encontrava, a fim de proteger da súbita chuva de granizo a motocicleta idêntica de A; o veículo de B é arruinado pelas pedras de gelo. Relutamos em aceitar que o texto do art. 24 alcance tal comportamento.

\section{0 significado da preferência do legislador pela teoria unitária}

Como se vê, cada uma das alternativas resumidas no início do item 3 oferece dificuldades decorrentes da fórmula legal vigente, às quais se somam os problemas indicados no item anterior. Parece-nos que a solução do problema passa por examinar melhor as intenções do legislador de 1940, mencionadas no item 1 , isolando-as e thes atribuindo o devido peso.

Os críticos da cisão do art. 24 em justificação e exculpação (item 2.1) alegam que esse expediente contraria o texto do art. 23 (antigo art. 19) e prejudica o réu. No entanto, parece-nos que, dentre os propósitos do legislador enumerados no início do item 1, o primordial é o de "transigir, ao menos em casos extremos, com a salvação de um bem à custa de outro de igual valor". Uma vez que se reconheça a primazia desse propósito do legislador, o atendimento dos demais, mais do que passar para um plano inferior, tem sua viabilidade condicionada pela decisão principal (isto é, pela opção do legislador de contemplar algumas situações de conflito de bens iguais). Em relação ao primeiro daqueles propósitos ("adotar a teoria unitária justificante"), mesmo que o legislador brasileiro não esteja sozinho na decisão de fixar a natureza jurídica de determinado instituto - haja vista ao texto expresso dos §§ 34 e 35 do CP alemão e dos arts. 34 e 35 do CP português, relativos aos EN justificante e exculpante -, é discutível que esses conceitos estejam à sua inteira disposição ${ }^{71}$.

Além disso, ainda no que se refere à comparação entre as soluções disponíveis, aquela que complementa o EN justificante com um exculpante também contraria a ambição do legislador de abraçar o critério unitário, como já visto ao final do item 2.2. A específica fórmula adotada, sem comparação direta entre os bens envolvidos, e com recurso ao "léxico da culpabilidade" (nota 40), tem a clara pretensão de esgotar o tratamento jurídico-penal do estado de necessidade (exceção feita, como visto no item 3, à coação irresistível), inibindo a complementação do texto legal pelo recurso à inexigibilidade de conduta diversa como

71 Assim, discordamos, em parte, de ZAFFARONI/BATISTA/SLOKAR/ALAGIA, que tratam como uma só as pretensões do legislador de deixar impune o náufrago e de reputar justificada sua conduta (ob. cit. [nota 4], p. 354: “0 legislador quis justificar a conduta do necessitado que sacrifica bem valorativamente idêntico ao salvo"). 
excludente da culpabilidade. Os autores que conservam o conflito de bens iguais sob a disciplina do art. 24 (o qual tomam como causa de justificação em todas as hipóteses), mas introduzem o EN exculpante para a ação voltada a salvar o bem de menor valor, no fundo ficam a meio caminho: querem possibilitar, ao menos em alguns casos, a isenção de pena de quem provoca um dano maior do que o evitado, mas não aceitam o preço consistente nas tensões internas de um conceito de justificação que se preste a garantir tal resultado. Bem examinadas, todas as soluções diferenciadoras se sujeitam à mesma crítica de desobedecer em alguma medida ao projeto do legislador.

\section{Esforço de solução: 0 desenvolvimento do conceito de (in)exigibilidade referido à justificação e à exculpação}

Antes de esboçar a solução que nos parece correta, cremos ser necessário sumariar rapidamente os problemas dos modelos propostos em doutrina:

1. A teoria unitária justificante explica mal a impunidade do agente no conflito entre bens iguais, comprometendo a própria noção de justificação, o que se agrava caso se admita o sacrifício do bem mais valioso em favor do menos valioso.

2. A subsunção de todas as hipóteses de estado de necessidade no art. 24 e posterior separação dessas hipóteses em justificação e exculpação contraria o expresso texto da rubrica do art. 23 e exige maior desenvolvimento em relação à fundamentação e aos limites de cada modalidade de EN.

3. A complementação do EN justificante previsto no art. 24 por um EN exculpante supralegal, nas formulações usuais, mantém as dificuldades inerentes à justificação de uma conduta que provoca mal equivalente ao que procura evitar, além de induzir uma duplicação da ideia de inexigibilidade a demandar melhor fundamentação.

4. A impunidade da ação que intervém no conflito entre bens equivalentes é materialmente insatisfatória quando a intervenção advém de terceiro não relacionado com os envolvidos ou quando os bens não são personalíssimos.

Cremos que a melhor solução para todos esses impasses foi sugerida por Gleizer $^{72}$ e consiste na redução do EN justificante do art. 24 aos seus devidos 
termos, e sua complementação por um EN exculpante supralegal ${ }^{73}$. Da proposta descrita no item 2.1, imita-se o esforço por respeitar os limites plausíveis do conceito de justificação, que deixa de alcançar o conflito de interesses iguais. Já da proposta vista no item 2.2 aceita-se a ideia de que o EN exculpante é supralegal, isto é, não está previsto no art. 24.

O ponto de partida para tal construção é o esforço de superação da crítica da "duplicação do conceito de inexigibilidade" que adiantamos no final do item 2.2: como conciliar o texto da lei com um EN exculpante baseado na inexigibilidade, sem substituir o critério da inexigibilidade eleito pelo próprio legislador como característico do EN justificante pelo critério, por ele evitado, da comparação direta de bens?

Parece-nos que a chave ${ }^{74}$ está em desenvolver a ideia de Henkel, segundo a qual a exigibilidade não caracteriza apenas um dos aspectos específicos do conceito de crime (ilicitude, culpabilidade), mas antes constitui um princípio jurídico regulatório que tem aplicação a cada um daqueles aspectos. Mais precisamente, um

princípio regulatório, que como tal não assinala o conteúdo preciso da decisão, mas sim o caminho que leva a ela, instruindo que se decidam os limites incertos de faculdades e deveres jurídicos segundo o conjunto de todas as circunstâncias perceptíveis do caso singular e através de uma concreta ponderação dos critérios valorativos que se apresentam. ${ }^{75}$

De acordo com tal premissa, a "duplicação do conceito de inexigibilidade" denunciada antes não ofereceria problema algum e seria mera decorrência da duplicidade de juízos de reprovação (ilicitude e culpabilidade). Concretamente, trata-se de responder à pergunta: $\mathrm{O}$ que significa inexigibilidade em sede de justificação da conduta e em sede de exculpação? ${ }^{76}$

73 São semelhantes nos resultados as propostas de PRADO, ob. cit. (nota 39), itens 7.9.1.1, p. 431, e 8.9.6, p. 553; e GALVÃO, ob. cit. (nota 3), cap. XI, n. 2.1.2, e cap. XII, n. 4.3.1 c); no entanto, esses autores não deixam claro se a disputa pela "tabula unius capax" seria subsumida no art. 24 e ainda assim considerada apenas exculpada (como em Fragoso e em Zaffaroni/Pierangeli), ou se eles a solucionariam pelo recurso ao EN exculpante supralegal (como proposto no texto).

74 Mencionada, porém não desenvolvida, por QUANDT, ob. cit. (nota 43), p. 208, nota 643. V. também as sugestões explícitas de duplicação citadas na nota 44, supra.

75 HENKEL, ob. cit. (nota 41), p. 73. Uma boa síntese do texto de Henkel é oferecida por ALBAN CERQUEIRA, Inexigibilidade de conduta diversa no pós-finalismo, p. 105.

76 A proposta de Henkel não ficou livre de opositores, alguns dos quais mencionados no estudo introdutório de Fernández e Guzmán (HENKEL, ob. cit. [nota 41], p. 22, notas 12 e 13). Um deles é Zaffaroni, que contesta 0 empobrecimento da noção de inexigibilidade no âmbito da exculpação e alerta para um suposto perigo de confundir 


\subsection{Inexigibilidade referida à justificação}

Em relação à exclusão da ilicitude, o que se propõe é que, em vez de se deformar o conceito de justificação incluindo nele as situações de conflito de bens iguais, se percorra o caminho inverso e se interprete o art. 24 a partir da rubrica do art. 23 ("exclusão de ilicitude"), compreendendo-se que o primeiro dispositivo citado se limita, portanto, à inexigibilidade referida à justificação ${ }^{77}$.

Para isso, toma-se como ponto de partida a comparação de males já referida e em alguma medida aceita pela doutrina nacional: a primeira condição para que uma conduta seja justificada pelo EN é que o malefício que ela provoca não seja superior ao que pretende evitar. Contudo, seria material e historicamente equivocado limitar o exame do alcance do art. 24 a uma simples ponderação de bens, com o que se perderiam todas as vantagens que uma cláusula flexível como a do art. 24 tem a oferecer ${ }^{78}$. De fato, a ponderação decisiva deve contemplar não apenas o valor abstrato dos bens envolvidos no conflito, como também todos os demais aspectos e interesses em jogo, de forma a garantir que o resultado dessa avaliação corresponda à solução final do Direito (no que se refere à licitude ou ilicitude do comportamento) para aquele conflito ${ }^{79}$. Assim, para além da comparação entre os valores dos bens afetados em si considerados (indiciados, dentre

os limites da ilicitude e da culpabilidade (ZAFFARONI, Tratado de Derecho Penal IV, n. 465, p. 72). De fato, ao propor a compreensão da inexigibilidade como princípio jurídico regulativo de aplicação não apenas em diversos setores do conceito de crime, mas em todos os ramos do Direito, Henkel expressamente postulou o esvaziamento material do conceito, que deixaria de ter conteúdo próprio como critério de exculpação (HENKEL, ob. cit. [nota 41], p. $96,115,119$ ). Não pretendemos enfrentar o problema das controvérsias sobre a consistência do conceito de inexigibilidade como causa geral de exculpação; o fato é que, ainda que se queira defender tal conceito, é imprescindível distingui-lo da inexigibilidade referida à justificação, a qual tem seu reconhecimento imposto no Brasil pelo texto expresso dos arts. 23 e 24. Desenvolvendo a ideia de inexigibilidade para a justificação, com alusão a Henkel, LUZÓN PEÑA, ob. cit. (nota 15), cap. 22, n. 149.

770 próprio Henkel emprega o conceito de inexigibilidade como princípio regulativo para a compreensão do estado de necessidade justificante, que na época não contava com uma previsão geral na lei alemã (HENKEL, ob. cit. [nota 41], p. 83). Contudo, ele adere à orientação da jurisprudência da época, consistente em exigir, para além da ponderação dos interesses em jogo, que o agente tenha efetuado um exame prudente das circunstâncias (ob. cit., p. 84). Crítico desse suposto "elemento subjetivo" do estado de necessidade, ESER/BURKHARDT, ob. cit. (nota 51), caso 12, A 51, p. 265. Mais recentemente, Roxin igualmente rechaçou essa exigência de "exame conforme ao dever", reconhecendo, porém, que ela nunca foi inteiramente abandonada pela jurisprudência (ROXIN, Derecho Penal PG I, § 14/81, p. 591). Em Portugal, v. DIAS, ob. cit. (nota 18), cap. 16º $§ 33$, p. 460.

Vantagens exaltadas por Sousa em relação à fórmula do CP/1969: SOUSA, ob. cit. (nota 29), p. 116 e 237.

79 Destacando com admirável eloquência e concisão a diferença entre a ponderação de bens e a de interesses, DIAS, ob. cit. (nota 18), cap. $16^{\circ}, \S 5$, p. 441. Igualmente distinguindo "interesse preponderante" de "bem jurídico que pesa mais em uma apreciação simplista", com inúmeras referências da doutrina alemã e espanhola, MOLINA FERNÁNDEZ, Revista de Derecho Penal y Criminologia [2a época], n. 1 (extra), p. 212. V. também HIRSCH, ob. cit. (nota 64), p. 130. Uma breve e convincente exposição de casos em que a simples ponderação de bens, abstratamente considerada, leva a resultados equivocados, é oferecida por LENCKNER, Rechtfertigung 
outros fatores, pelas penas cominadas aos delitos que os violam $)^{80}$, devem-se examinar diversos outros aspectos ${ }^{81}$, tais como: a extensão dos danos decorrentes do perigo originário e da ação salvadora (evitar-se uma lesão corporal gravíssima causando um pequeno ferimento em outrem) ${ }^{82}$; a intensidade do perigo representado pela situação de necessidade ${ }^{83}$ (riscos maiores autorizam reações mais intensas); a probabilidade de dano ínsita à ação salvadora ${ }^{84}$ (ações de salvamento mais perigosas demandam uma justificação particularmente convincente); a reparabilidade do dano ${ }^{85}$ (danos reparáveis são mais fáceis de justificar que os irreparáveis); a probabilidade de êxito da ação voltada à salvação, que deve ser idônea ex ante para a finalidade a que se $\operatorname{presta}^{86}$ (o insucesso da ação de salvamento não impede por si só sua justificação, a menos que esse fracasso fosse óbvio desde o princípio $^{87}$ ).

Além disso, a complementação do juízo comparativo entre os bens com outras variáveis talvez permita que se considere a distinção entre estado de necessidade agressivo e defensivo. Como se sabe, no primeiro a ação salvadora se volta contra os bens de um terceiro não implicado, ao passo que no segundo a ação justificada se volta contra a própria fonte do perigo. A distinção é frequente-

und Entschuldigung, p. 497. Entre nós, v. SOUSA, ob. cit. (nota 29), p. 239, 242 e 252; ZAFFARONI/BATISTA/ SLOKAR/ALAGIA, ob. cit. (nota 4), p. 121.

80 BACIGALUPO, Derecho Penal PG, n. 737, p. 378; CORREIA, ob. cit. (nota 55), p. 85; vejam-se, porém, as prudentes ressalvas de DIAS, ob. cit. (nota 18), cap. $16^{\circ}$, $\$ 13$, p. 446; JAKOBS, ob. cit. (nota 51), ap. 13, n. 20, p. 504, e a crítica breve, mas incisiva, de GARCíA CAVERO, Casos que hicieron doctrina en Derecho penal, p. 138.

81 Para uma ampla relação dos aspectos em jogo - alguns dos quais mencionados no texto - ESER/BURKHARDT, ob. cit. (nota 51), caso 12, A 33, p. 260; ROXIN, ob. cit. (nota 77), § 16, n. 22, p. 682; JESCHECK/WEIGEND, Tratado de Derecho penal PG, § 33, IV, 3, c, p. 388; WESSELS/BEULKE/SATZGER, ob. cit. (nota 16), n. 459, p. 196; HILGENDORF/VALERIUS, ob. cit. (nota 11), § 5/82, p. 146, CUELLO CONTRERAS, ob. cit. (nota 14), cap. X, n. 189, p. 865; DIAS, ob. cit. (nota 18), cap. 16º $\S 11$ e ss., p. 445 e ss.; LUZÓN PEÑA, ob. cit. (nota 15), cap. 24, n. 34. No Brasil, vejam-se SANTOS, ob. cit. (nota 18), p. 258; LEITE, ob. cit. (nota 14), p. 80; ZAFFARONI/PIERANGELI, ob. cit. (nota 12), n. 342, p. 516.

82 EISELE, ob. cit. (nota 5), p. 509; CEREZO MIR, ob. cit. (nota 10), p. 672; JAKOBS, ob. cit. (nota 51), ap. 13, n. 26, p. 510.

83 BATISTA, ob. cit. (nota 4), p. 513; CEREZO MIR, ob. cit. (nota 10), 672 e 696; JAKOBS, ob. cit. (nota 51), ap. 13, n. 30, p. 512.

84 CEREZO MIR, ob. cit. (nota 10), p. 672.

85 CEREZO MIR, ob. cit. (nota 10), p. 672 e 696.

86 Assim, já o texto do art. 33, 3ํ, do CP/1890. Na Espanha, LUZÓN PEÑA, ob. cit. (nota 15), cap. 24, n. 19; v. também SAINZ-CANTERO CAPARRÓS, ob. cit. (nota 33), p. 374.

87 CORREIA, ob. cit. (nota 55), p. 87; SOUSA, ob. cit. (nota 29), p. 55. Ambíguos entre a exigência de aptidão salvadora aferida ex ante e de sucesso ex post da ação salvadora, ZAFFARONI/BATISTA/SLOKAR/ALAGIA, ob. cit. (nota 4), p. 120. 
mente esboçada pelos autores nacionais ${ }^{88}$, mas são poucos os que indicam a sua finalidade ${ }^{89}$, que seria conferir maior amplitude ao EN defensivo, aproximando-o da legítima defesa ${ }^{90}$.

Confinando com o EN defensivo, há situações em que duas ou mais pessoas são ameaçadas pelo perigo, e apenas uma ou algumas delas, previamente definidas pelas circunstâncias, têm chance de se salvar: é o que ocorre quando dois alpinistas estão pendurados na mesma corda, que não suportará a ambos por muito tempo, e somente o alpinista de cima pode sobreviver, cortando a parte da corda que sustenta o de baixo. Em situações assim, há quem defenda a possibilidade de sacrifício justificado do bem inevitavelmente comprometido, a fim de salvar-se o bem com chances de preservação ${ }^{91}$.

88 HUNGRIA, ob. cit. (nota 19), n. 92, p. 278; JESUS, ob. cit. (nota 13), p. 423; MIRABETE, ob. cit. (nota 13), n. 4.2.2, p. 180; TOLEDO, ob. cit. (nota 3), n. 163, p. 176; NUCCI, ob. cit. (nota 15), cap. XXII, n. 4.2.2; SOUSA, ob. cit. (nota 29), p. 9; GRECO, ob. cit. (nota 45), p. 387; BUSATO, ob. cit. (nota 35), p. 475; GALVÃO, ob. cit. (nota 3), n. 7.9.1, p. 431.

89 Entre as escassas exceções estão LEITE, ob. cit. (nota 14), p. 82; EISELE, ob. cit. (nota 5), p. 511; ZAFFARONI/ BATISTA/SLOKAR/ALAGIA, ob. cit. (nota 4), p. 108. Em defesa da doutrina nacional, convém lembrar que, segundo Wilenmann, a doutrina chilena geralmente ignorava a distinção entre estado necessidade defensivo e agressivo (WILENMANN, ob. cit. [nota 33], p. 217).

90 Extensamente sobre o EN defensivo, HIRSCH, Derecho penal V, p. 105-138. No Brasil, Marques, Pacelli e Callegari associam a contraposição defensivo $\mathrm{x}$ agressivo aos problemas do dever de indenizar, o que - correto ou não perante a disciplina expressa do CC - não corresponde à razão de ser da distinção no Direito Penal (MARQUES, ob. cit. [nota 10], § 68, 8, p. 132; PACELLI/CALLEGARI, Manual de direito penal PG, p. 253). Na Alemanha, a ideia de conferirem-se limites mais amplos ao estado de necessidade defensivo tem um ponto de apoio claro (ainda que limitado), pois o Código Civil prevê expressamente o EN defensivo contra coisas (§ 228), com regras mais vantajosas para o defendente do que as do EN agressivo (previsto no $§ 904$ do CC alemão). De nossa parte, não encontramos amparo explícito na lei brasileira (como o § 228 do CC alemão, já referido) para legitimar o maior elastério do EN defensivo quando comparado ao agressivo, e deixamos em aberto o problema de sua justiça intrínseca - embora reconhecendo que, na Espanha, onde a lei não prevê especificamente o EN defensivo, alguns autores postulam sua legitimidade (LUZÓN PEÑA, ob. cit. [nota 15], cap. 24, n. 50; MIR PUIG, ob. cit. [nota 5], lição 17/69, p. 470), e que o EN defensivo ganha importância à medida que se incrementam as restrições à legítima defesa (HIRSCH, H. J., ob. cit., p. 108; ROXIN, Sistema del hecho punible/2, p. 468; PERRON, ob. cit. [nota 27], p. 182; JAKOBS, ob. cit. [nota 51], ap. 13, n. 46, p. 520). Sobre o estado de necessidade defensivo, são muito úteis - justamente porque pautadas em uma lei que não o prevê expressamente - as considerações de DIAS, ob. cit. (nota 18), cap. $16^{\circ}, \S 34$, p. 460 . De toda forma, a aceitação do EN defensivo deixa em aberto o peso do critério que o caracteriza: na Alemanha, geralmente se exige apenas que o dano causado pela ação defensiva não seja desproporcionalmente maior que o dano evitado (v., p. ex., ROXIN, ob. cit. [nota 77], § 16, n. 65, p. 706; HIRSCH, op. cit., p. 132); já Baldó e Cerezo, por exemplo, não se dispõem a ir além da equivalência dos danos, ao menos de lege lata (BALDÓ LAVILLA, ob. cit. [nota 59], p. 24, CEREZO MIR, ob. cit. [nota 10], p. 694, nota 126); a divergência de opiniões visivelmente reflete as peculiaridades do Direito positivo de cada país.

91 Referências em SANTOS, ob. cit. (nota 18), p. 262. Contra a justificação em tais casos, ROXIN, ob. cit. (nota 77), $\S 16$, n. 31, p. 687; CANO PAÑOS, Casos que hicieron doctrina en Derecho penal, p. 920; CORREIA, ob. cit. (nota 55), p. 94. Segundo Dias, que é favorável à justificação do sacrifício de quem está "marcado pelo destino", na expressão de Eb. Schimidt (DIAS, ob. cit. [nota 18], cap. 16² § 22, p. 454), o exemplo já era utilizado por Merkel em 1895 (ob. cit., cap. $16^{\circ}$, § 20, p. 453). 
Tomados em consideração os critérios a serem ponderados, é preciso estabelecer o limite da justificação. Como insistentemente adiantado no texto, a simples equivalência dos interesses contrapostos não é suficiente para justificar a conduta que promova a salvação de um bem à custa de outro ${ }^{92}$. A questão, também já adiantada de alguma forma no texto (nota 26), é determinar se basta a mínima superioridade dos interesses favoráveis ao bem salvo pela ação típica ou se é preciso exigir um saldo maior em favor da ação de salvamento para justificá-la. O art. 43 do CPM exige que "o mal causado, por sua natureza e importância", seja "consideravelmente inferior" ao evitado; os CP alemão e português, por sua vez, demandam "substancial" e "sensível superioridade", respectivamente ${ }^{93}$.

Mir, cuja solução para o art. 20.5 do CP espanhol decerto é reconhecível na presente proposta ${ }^{94}$, sugere que a prática da ação salvadora provoca uma perturbação na ordem jurídica, e, sendo individual o bem afetado, uma ingerência anormal na esfera do lesionado. Por essa razão, para que o mal causado seja não superior ao evitado, nos termos da lei espanhola, seria preciso que os demais interesses contrapostos indiquem, com considerável vantagem, a salvação do bem originalmente ameaçado, a fim de que se compense a referida perturbação ${ }^{95}$. Embora outros autores objetem que a ordem jurídica não sofre perturbação alguma

92 FRISTER, Derecho Penal PG, cap. 17, n. 9, p. 347. Embora apelando também ao valor da dignidade humana, a formulação de Mir refuta convincentemente a suficiência da equivalência de males: "El amenazado de muerte no tiene derecho alguno a trasladar su problema a otro no afectado" (MIR PUIG, ob. cit. [nota 5], lição 17/71, p. 472 - v. porém a nota 97, infra). V. também a opinião de Luzón na nota 68, supra.

93 O mesmo problema da interpretação do termo "manifestamente" no texto de Hungria (nota 26, supra) se repete na interpretação dos termos empregados nas referidas leis estrangeiras para definir o EN justificante: embora as palavras em questão pareçam sugerir a exigência de diferença acentuada entre o bem salvo e o sacrificado, alguns autores entendem que ela precisa ser apenas "indubitável e inequívoca" (ROXIN, ob. cit. [nota 77], § 16, n. 77, p. 713; JESCHECK/WEIGEND, ob. cit. [nota 81], § 33, IV, 3, c, p. 388; DIAS, ob. cit. [nota 18], cap. 16² § 26, p. 456). Exigindo "considerável" preponderância de interesses, WESSELS/BEULKE/SATZGER, ob. cit. (nota 16), n. 458, p. 195; ESER/BURKHARDT, ob. cit. (nota 51), caso 12, A 36, p. 261; JAKOBS, ob. cit. (nota 51), ap. 13, n. 33, p. 513.

94 Mir também sugeriu restringir o EN legal e complementá-lo com um EN supralegal exculpante, ou com a eximente do medo insuperável previsto na lei espanhola (MIR PUIG, ob. cit. [nota 5], lição 17/29, p. 459). Ao contrário do brasileiro, o Código Penal espanhol não informa a natureza jurídica do EN nele previsto, e o define em termos de comparação explícita de males. Apesar disso, é possível enxergar certa correspondência entre as propostas nacionais e as avançadas na Espanha, tais como resumidas por SILVA SÁNCHEZ, ADPCP 35, p. 663: lá como cá, há quem defenda a teoria unitária justificante (GIMBERNAT ORDEIG, ob. cit. [nota 54], passim; LUZÓN PEÑA, ob. cit. [nota 15], cap. 24, n. 8), e quem proponha o fracionamento do EN legal em justificação e exculpação (ANTÓN ONECA, Derecho Penal, p. 296 e 301). Na opinião de vários autores, esta última solução é a dominante na Espanha (SILVA SÁNCHEZ, ob. e loc. cit.; GIMBERNAT ORDEIG, ob. cit., p. 218; LUZÓN PEÑA, ob. cit., cap. 24, n. 4; CEREZO MIR, ob. cit. [nota 10], p. 676, SAINZ-CANTERO CAPARRÓS, ob. cit. [nota 33], p. 348). MIR PUIG, ob. cit. (nota 5), lição 17/26, p. 458, e 17/67, p. 469. 
pela prática de uma ação justificada ${ }^{96}$, cremos que a exigência de Mir quanto à considerável superioridade dos interesses preservados pela ação típica, apesar de mal formulada, está materialmente correta ${ }^{97}$.

Por fim, devem-se lembrar as proposições segundo as quais a ponderação de interesses encontra limites intransponíveis na especial posição ocupada pelos bens jurídicos superiores. Assim, na Alemanha geralmente se postula que o homicídio doloso não pode ser justificado pelo estado de necessidade agressivo, em razão da intangibilidade da vida humana; ${ }^{98}$ nem mesmo a superioridade numérica das vidas a salvar derrogaria essa limitação $0^{99}$. Na Espanha, Cerezo destaca a exigência de respeito à dignidade alheia, que impede, por exemplo, a extração forçada de órgãos para transplante ${ }^{100}$.

96 CEREZO MIR, ob. cit. (nota 10), p. 684; SAINZ-CANTERO CAPARRÓS, ob. cit. (nota 33), p. 378.

97 Em razão do texto legal de seu país, Mir considera a perturbação e a intromissão decorrentes da ação salvadora um mal a mais a ser ponderado - como um peso, diríamos, a colocar-se em uma balança de pratos que deve ficar equilibrada ou pender para o lado da ação salvadora. Uma consequência indevida da formulação de Mir é que ele aceita a justificação em alguns conflitos entre vidas, porque a perturbação da ordem jurídica já adviria do perigo decorrente do naufrágio (MIR PUIG, ob. cit. [nota 5], lição 17/68, p. 470). A inconsistência da exceção proposta por Mir é corretamente denunciada por CUELLO CONTRERAS, ob. cit. [nota 14], cap. X, n. 183, p. 862, nota 339. Antón, com melhor critério, fundamenta a exigência de considerável desproporção entre os interesses em conflito (ANTÓN ONECA, ob. cit. [nota 94], p. 296) - desproporção em favor do bem a ser salvo - no respeito devido por toda pessoa à esfera de direitos do próximo (ob. cit., p. 293), inclusive com sacrifício próprio, que só cede em circunstâncias graves e extraordinárias (ob. cit., p. 297). Perante a lei brasileira, talvez seja melhor considerar essa intromissão na esfera de direitos alheia não exatamente como um mal adicional a ser compensado, mas como 0 motivo para exigir-se a considerável preponderância dos interesses refletidos na ação típica.

98 Em coerência com nossa opção por não aprofundar a discussão sobre o EN defensivo (nota 90), apenas registramos a controvérsia sobre a possibilidade justificar-se, por ele, a morte dolosa de alguém. Vejam-se as referências em ambos os sentidos em WESSELS/BEULKE/SATZGER, ob. cit. (nota 16), n. 465, p. 199; HIRSCH, ob. cit. (nota 64), p. 133, nota 41.

99 ESER/BURKHARDT, ob. cit. (nota 51), caso 12, A 24, p. 258; HILGENDORF/VALERIUS, ob. cit. (nota 11), § 5/83, p. 146; JESCHECK/WEIGEND, ob. cit. (nota 88), § 33, IV, 3, c, p. 389. V., porém, as matizações de JAKOBS, ob. cit. (nota 51), ap. 13, n. 21, p. 505. Os autores alemães geralmente fundamentam essa limitação na exigência de adequação contida no final do § 34 do Código Penal daquele país, cujo exato conteúdo ainda é controvertido. Em Portugal, Correia propõe algo semelhante a essa exigência de adequação aludindo à inexigibilidade do sacrifício do bem pela ação de salvamento, concluindo adiante pela impossibilidade de justificação do homicídio pela comparação numérica entre os salvos e os sacrificados (CORREIA, ob. cit. [nota 55], p. 85 e p. 95, respectivamente). Entre os autores portugueses mais recentes, veja-se DIAS, ob. cit. (nota 18), cap. $16^{\circ}, \S 17$, p. 450 . A doutrina alemã da impossibilidade de contagem de vidas para justificação do salvamento do maior número já era noticiada entre nós por JESUS, Ciência penal 1, p. 89-98; FRAGOSO, ob. cit. (nota 27), n. 202, p. 220; e SOUSA, ob. cit. (nota 29), p. 124, 169 e 230. De toda forma, não faltam autores que, sob determinadas condições, aceitam a ponderação quantitativa de vidas: LUZÓN PEÑA, ob. cit. (nota 15), cap. 24, n. 37; ORTIZ DE URBINA GIMENO, Casos que hicieron doctrina en Derecho penal, p. 190.

100 CEREZO MIR, ob. cit. (nota 10), p. 686, seguido entre nós por seu discípulo PRADO, ob. cit. (nota 39), item 2.1.2, texto prévio à nota 54. V. também SOUSA, ob. cit. (nota 29), p. 116 e 232; MINORELLI/CAETANO, ob. cit. (nota 64), p. 288; ZAFFARONI/BATISTA/SLOKAR/ALAGIA, ob. cit. (nota 4), p. 117; MIR PUIG, ob. cit. (nota 5), lição 17/71, p. 471; LUZÓN PEÑA, ob. cit. (nota 15), cap. 24, n. 42; BARJA DE QUIROGA, ob. cit. (nota 33), p. 655. Em Portugal, Dias trata do problema do transplante e da transfusão de sangue forçados sob a rubrica da 
Tomados esses parâmetros em consideração, o art. 24 poderia ser lido assim:

Art. 24. Considera-se em estado de necessidade justificante quem pratica o fato para salvar de perigo atual, que não provocou por sua vontade, nem podia de outro modo evitar, direito próprio ou alheio, cujo sacrifício, considerando a ponderação entre os bens envolvidos, a origem do perigo e sua extensão, as características da ação salvadora, e demais circunstâncias relevantes, não era razoável exigir-se. ${ }^{101}$

Ou, em termos mais sintéticos: "Art. 24. É justificada a ação de salvamento quando não houver alternativas mais amenas e, ponderadas todas as circunstâncias relevantes, ela for justa no caso concreto".

Com isso, como dito, aproveita-se o potencial que o art. 24 oferece em termos de flexibilidade, introduzindo-se no juízo de ponderação todas as circunstâncias relevantes, evitando-se a rigidez e as necessidades de correção da simples ponderação de bens, que o legislador deliberadamente evitou.

\subsubsection{A posição da provocação prévia do perigo e do dever de enfrentá-lo}

$\mathrm{O}$ art. 24 exige, para o reconhecimento do estado de necessidade, que o agente não haja provocado voluntariamente o perigo e que não tenha o dever legal de enfrentá-lo (art. 24, caput e $\S 1^{\circ}$, respectivamente). A redação dos dispositivos parece conferir autonomia àquelas exigências, cuja verificação precederia o exame da exigibilidade. Ambos os requisitos propõem alguns problemas que não detalharemos, tais como o de determinar a quem eles se referem no caso de auxílio necessário (à vítima do perigo originário ou ao agente que presta o auxílio?) ${ }^{102}$; se a provocação voluntária é apenas a dolosa ou também a culposa, e qual seu objeto (o perigo ou a situação de necessidade) ${ }^{103}$; e os limites do

autonomia pessoal do lesado, que expressamente distingue da dignidade da pessoa, e insiste que se trata de um aspecto a mais a ser sopesado na ponderação de interesses, e não propriamente um limite intransponível (DIAS, ob. cit. [nota 18], cap. $16^{\circ}, \S 16$, p. 449). Na Espanha, Molina também reinterpreta os limites intransponíveis à ponderação como simples fatores a integrá-la - ainda que para definir a ponderação em um sentido fixo para todas as hipóteses que envolvam aqueles fatores (MOLINA FERNÁNDEZ, ob. cit. [nota 79], p. 214). Sobre o ponto, v. também CEREZO MIR, ob. cit. (nota 10), p. 688, com referências adicionais.

101 Compare-se com a fórmula proposta de lege ferenda de Luís Greco e colaboradores: "Não atua ilicitamente quem comete o fato para salvar um bem de perigo atual, não evitável de outro modo, desde que a ponderação de todos os aspectos do fato revele haver sensível superioridade do interesse a ser preservado em relação àquele a ser sacrificado". GRECO et al., Parte geral do Código Penal, p. 31. V. também a nota 108, infra.

102 CEREZO MIR, ob. cit. (nota 10), p. 706.

103 CEREZO MIR, ob. cit. (nota 10), p. 704. 
dever de enfrentar o perigo - uma vez que a doutrina insiste que esse dever não obriga o sujeito onerado a sujeitar-se à morte certa ${ }^{104}$, e que mesmo o dever do bombeiro de enfrentar a morte não incide para a salvação de bens meramente patrimoniais ${ }^{105}$. Os problemas mencionados convidam à inserção dos requisitos em análise na avaliação da própria exigibilidade: o dever de enfrentar o perigo, por exemplo, não seria um requisito de constatação binária (presente/ausente), mas uma magnitude graduável (dever de intensidade variável) que integraria o exame da exigibilidade ${ }^{106}$. Esse, aliás, o caminho seguido pela lei alemã, que inclui na ponderação de interesses os problemas da provocação do perigo e do dever de evitá-lo, e os indica como fatores impedientes unicamente do EN exculpante $\mathrm{e}^{107-108}$.

Além disso, a retirada da autonomia dos requisitos antes examinados e sua transposição para o exame da exigibilidade têm consequências não apenas para a apuração da incidência do caput do art. 24, mas também para a aplicação do $\S 2^{\circ}$ do art. 24: naquelas hipóteses em que o dever de enfrentar o perigo tornasse exigível o sacrifício do agente, talvez fosse possível aplicar a referida causa de redução de pena. Tomadas as exigências de não haver provocado o perigo e de não ter o dever de enfrentá-lo como requisitos autônomos e absolutos da própria situação de necessidade, o não atendimento dessas exigências parece inibir a aplicação não apenas do caput, como também do $\S 2^{\circ}$. O tema, contudo, exigiria um exame à parte.

\subsection{Inexigibilidade referida à exculpação}

Quanto à exculpação, a inexigibilidade se referiria à dificuldade de motivar-se pela proibição, em razão de circunstâncias particulares que tornassem especialmente custosa a abstenção da ação salvadora - ou seja, àquilo que geralmente

104 CEREZO MIR, ob. cit. (nota 10), p. 709; ESER/BURKHARDT, ob. cit. (nota 51), caso 18, A 31, p. 379; SOUSA, ob. cit. (nota 29), p. 94 e 250; ZAFFARONI/BATISTA/SLOKAR/ALAGIA, ob. cit. (nota 4), p. 124 e 359.

105 GÓMEZ BENÍTEZ, Teoría jurídica del delito, p. 385.

106 Derivando os requisitos da não provocação voluntária do perigo e da inexistência do dever de enfrentá-los da ideia de exigibilidade, ALBAN CERQUEIRA, Uma releitura do conceito analítico de crime através do princípio da exigibilidade, p. 136.

107 V., p. ex., ESER/BURKHARDT, ob. cit. (nota 51), caso 12, A 34, p. 260.

108 Em complemento à nota 101, supra, veja-se a fórmula proposta de lege ferenda de Luís Greco e colaboradores: "§ $1^{\circ} \mathrm{A}$ ponderação a que alude o caput deverá levar em conta sobretudo a natureza e o valor dos bens envolvidos, a intensidade e a origem do perigo que os atinge e a existência de um dever jurídico de enfrentá-lo". GRECO et al., ob. cit. (nota 101), p. 31. Também de lege ferenda, Cerezo propõe que a ausência de provocação do perigo e o dever de enfrentá-lo sejam tratados dentro da ponderação de interesses, no EN justificante, e sejam previstos apenas no EN exculpante como fatores fundamentadores da exigibilidade da conduta diversa (CEREZO MIR, ob. cit. [nota 10], p. 706 e 710). 
se chama, sem mais, "inexigibilidade"109. Essa dificuldade de motivação, aliada à redução do injusto decorrente da finalidade salvadora da conduta típica (pois matar alguém para salvar-se do perigo sério de mutilação é menos desvalorado que simplesmente matar), reduziria a culpabilidade a um nível insuficiente para legitimar a imposição da pena ${ }^{110}$. Nesse ponto, é preciso prestar contas à crítica corrente à inexigibilidade de conduta diversa como causa de exculpação, consistente em denunciar-Ihe a falta de fundamento material e contornos claros ${ }^{111}$. A primeira objeção pode ser formulada pelo exemplo tantas vezes invocado no texto: uma vez excluído do âmbito do art. 24 o caso da "tabula unius capax", como explicar a impunidade dos náufragos, claramente desejada pelo legislador histórico?

Para dar resposta a ambas as questões, parece-nos possível acudir a três fontes. A primeira é a previsão legal da coação irresistível ${ }^{112}$. De fato, a doutrina dominante enxerga ali a simples exculpação (item 3), e não encontramos voz alguma a condicionar a aplicação do art. 22 à superioridade do mal ameaçado pelo coator em relação ao mal praticado pelo coato; em particular, cremos que ninguém discutiria a possibilidade de exculpação de quem mata um terceiro para não ser morto pelo coator. Mas, se a ameaça de um mal equivalente ao mal praticado pelo coato é suficiente para excluir a culpabilidade, o mesmo tem de se reconhecer quando o perigo advém de um desastre natural, por exemplo ${ }^{113}$. Assim, o paralelo com a coação irresistível - cuja emancipação em relação ao estado de necessidade foi explicada no item 3 e não tem como fundamento a imposição de limites mais generosos a quem pratica uma ação sob coação propriamente dita

109 V. nota 76.

110 HIRSCH, ob. cit. (nota 64), p. 144; HIRSCH, ob. cit. (nota 14), p. 47; JESCHECK/WEIGEND, ob. cit. (nota 88), § 43 । 2, p. 512, e III 2 b, p. 514; CEREZO MIR, ob. cit. (nota 10), p. 691; WESSELS/BEULKE/SATZGER, ob. cit. (nota 16), n. 653, p. 301 etc. A ideia de dupla redução da culpabilidade (de modo reflexo, pela redução do conteúdo do injusto, e de modo direto, pela pressão motivacional) é creditada em toda parte a Armin Kaufmann (KAUFMANN, Dogmática de los delitos de omission, p. 170 e ss.); v., p. ex., ROBLES PLANAS, Casos que hicieron doctrina en Derecho penal, p. 116. Certamente, essa não é a única fundamentação possível para o EN exculpante: v. outras formulações em ESER/BURKHARDT, ob. cit. (nota 51), caso 18, A 10, p. 372. Entre nós, a ideia de que no estado de necessidade exculpante sempre há uma redução do injusto é posta em dúvida por ZAFFARONI/BATISTA/SLOKAR/ALAGIA, ob. cit. (nota 4), p. 353.

111 V., entre vários outros, ROBLES PLANAS, ob. cit. (nota 110), p. 117.

112 Semelhante, GLEIZER, ob. cit. (nota 11), § 5, n. 145, p. 169. Bitencourt também apela à coação irresistível para fundamentar o EN supralegal exculpante (embora, em sua proposta, o EN justificante alcance os conflitos entre males iguais): BITENCOURT, ob. cit. (nota 13), cap. XXI, item 5.1.

113 Chiesa informa que o Model Penal Code norte-americano é mais indulgente com a vítima de coação do que com a de um desastre natural, mas igualmente lembra que os comentadores daquele texto propõem a equiparação das situações (CHIESA, Casos que hicieron doctrina en Derecho penal, p. 107). Para uma apresentação do Model Penal Code, LUCCHESI, RBCCrim 178, p. 149-169. 
do que a quem pratica a mesma ação por uma "coação" da natureza - permite fundamentar satisfatoriamente a impunidade do náufrago que desaloja outro da "tabula unius capax", tal como desejado pelo legislador histórico, sem forçar os limites da noção de justificação.

O segundo ponto legal de apoio para o estado de necessidade exculpante é o CPM, que, como dito no item 1, acolheu uma fórmula diferenciadora e indicou, no art. 39, algumas exigências para o reconhecimento da inexigibilidade exculpante, ao limitar o círculo de potenciais agentes à própria vítima do perigo e a pessoas a ela ligadas "por estreitas relações de parentesco ou afeição". A previsão de alguma limitação subjetiva para o EN exculpante também aparece no $§ 35$ do Código alemão ${ }^{114}$, e se explica facilmente: o Direito reconhece a dificuldade do pai de se abster de matar um terceiro para salvar a vida de seu filho, mas não reconhece idêntica dificuldade quanto a um terceiro estranho aos envolvidos, nem transige com motivações inspiradas no ódio contra aquele a ser sacrificado pela ação salvadora, por exemplo. Com isso, contorna-se o problema identificado no item 4.1 - qual seja, do terceiro como "juiz do caso" - pois a condescendência da lei só alcançará a pretensão do terceiro de escolher o vitorioso se o vínculo afetivo explicar satisfatoriamente sua intervenção no conflito; ainda assim, sua conduta não estará justificada, mas apenas exculpada.

O terceiro e último ponto de apoio legal para o reconhecimento da noção de inexigibilidade e, sobretudo, para a definição dos limites do círculo de possíveis beneficiados pela isenção de pena, se extrai daquelas causas de exculpação contidas na Parte Especial, como a que isenta de pena o ascendente, descendente, cônjuge ou irmão que prestam favorecimento pessoal (art. 348, § 2º $)^{115}$. Embora a doutrina tradicionalmente as interprete como causas pessoais de exclusão de

114 “(1) Aquele que comete um ato antijurídico para afastar de si, de um parente ou de uma pessoa próxima um perigo atual para a vida, o corpo ou a liberdade, que não seja evitável de outra maneira, atua sem culpabilidade. Isso não se aplica caso, dadas as circunstâncias, pudesse ser exigido do autor que suportasse o perigo, especialmente porque ele próprio criou o perigo ou porque ele se encontrava em uma relação jurídica especial; no entanto, a pena pode ser atenuada com base no $\$ 49$ Abs. 1, caso o autor tenha que suportar o perigo por outra razão que não seja uma especial relação jurídica. (2) Caso o autor, ao cometer o fato, suponha, por erro, circunstâncias que o exculpariam segundo a Absatz 1 , ele só será penalizado caso ele pudesse ter evitado o erro. A pena deve ser atenuada com base no § 49 Abs. 1." (Transcrito segundo a tradução de GLEIZER, ob. cit. [nota 11], § 6/45, p. 187)

115 Utilizando a previsão do favorecimento pessoal como possível fundamento para um EN exculpante supralegal, LUZÓN PEÑA, ob. cit. (nota 15), cap. 28, n. 57. Invocando o crime de favorecimento para limitar o rol de pessoas no EN exculpante, ZAFFARONI, ob. cit. (nota 76), n. 501, p. 249; ZAFFARONI/BATISTA/SLOKAR/ALAGIA, ob. cit. (nota 4), p. 357. 
pena, sua verdadeira natureza jurídica de causa de exculpação aos poucos vem sendo reconhecida ${ }^{116}$.

Ainda no que se refere a este último problema - da delimitação dos sujeitos aptos a invocar a exculpação quando praticam a ação em auxílio de outrem ${ }^{117}$-, pode-se postular a preferência pela não limitação apriorística do rol de possíveis beneficiários da ação salvadora não justificada, tal como no art. 35 do CP português, o que permite considerar exculpadas ações salvadoras em casos especialmente dramáticos, em que um sujeito não implicado, sem vínculo afetivo com os envolvidos, pratica um injusto penal para evitar um mal drástico: o exemplo mais recorrente é o dos médicos do $3^{\circ}$ Reich, que, recebendo do regime nazista a ordem de refinar um rol de pacientes com transtorno mental previamente elaborado (pacientes cujo destino certo era a morte), esforçaram-se por eliminar tantos nomes quanto conseguiram e participaram do posterior traslado dos pacientes que permaneceram na lista, os quais em sua maioria morreram. Após o término da guerra, defenderam-se alegando que, caso se recusassem a tomar parte do massacre, seriam substituídos por pessoas menos comprometidas com reduzir ao máximo o rol de pacientes a serem sacrificados ${ }^{118}$.

116 Classificando a previsão legal como "escusa absolutória", NUCCI, ob. cit. (nota 15) cap. XLII, n. 3. No sentido do texto, PRADO, ob. cit. (nota 39), cap. XII, item 4.3; CARVALHO, Ciências Penais 6, p. 174-198, com referências adicionais para ambas as classificações na nota 52. V. também HIRSCH, ob. cit. (nota 14), p. 40; ZAFFARONI/ BATISTA/SLOKAR/ALAGIA, ob. cit., (nota 4), p. 357.

117 Nos países cujas leis contêm dispositivos que são interpretados como disciplinadores de um EN exculpante, mas que não fazem exigências quanto ao vínculo entre o agente e o beneficiado pela ação salvadora, são comuns as polêmicas relativas à introdução de tais requisitos. Na Espanha, a favor de limitações pessoais para o EN exculpante, mesmo sem previsão expressa no art. 20, 5, do CP daquele país: ANTÓN ONECA, ob. cit. (nota 94), p. 302; segue-o CEREZO MIR, ob. cit. (nota 10), p. 692. Hirsch, por sua vez, alertou para as dificuldades de conciliação dessa exigência com o texto legal espanhol (HIRSCH, ob. cit. [nota 64], p. 125); como destaca SainzCantero, a lei é livre para delimitar a inexigibilidade de outra conduta (SAINZ-CANTERO CAPARRÓS, ob. cit. [nota 33], p. 352). Vejam-se ainda as considerações de JIMÉNEZ DE ASÚA, Tratado de Derecho penal IV, n. 1.361, p. 376. Igualmente aceitando o EN exculpante (que ele, justamente para evitar as controvérsias referidas nas notas 18 e 38, supra, denomina "situações de necessidade que não implicam deveres de tolerância", isto é, não constituem justificações no sentido descrito no item 1) em favor do terceiro não implicado que atua na definição de conflitos de bens iguais, com extensa fundamentação, SILVA SÁNCHEZ, ob. cit. (nota 69), passim. No Chile, o novo e intrigante item 1 do art. 10 do CP é interpretado como causa de exculpação por Mañalich, quem tenta explicar a dispensa de qualquer vínculo pessoa do interveniente em relação ao fato (MAÑALICH RAFFO, LHEnrique Cury, p. 734). No Brasil, a exigência de proximidade entre o agente e a vítima do perigo originário já é feita quanto à coação irresistível, mesmo sem expressa previsão legal: v., p. ex., MIRABETE, ob. cit. (nota 13), n. 5.3.2, p. 207. Neste contexto, não vemos problema algum em introduzir semelhante exigência em uma causa de exculpação supralegal.

118 Esse caso é referido em toda parte, nem sempre com idêntica descrição. Aquela oferecida no texto se baseia no resumo de ORTIZ DE URBINA GIMENO, ob. cit. (nota 99), p. 177. Reconhecendo certa vantagem na legislação portuguesa por não prever o rol de possíveis intervenientes no EN exculpante, com expressa alusão ao caso descrito no texto, DIAS, ob. cit. (nota 18), cap. 22, § 19, p. 614. Na Alemanha, a exculpação de pessoas que não atuem 
Em relação aos demais requisitos do EN exculpante - em especial quanto aos bens passíveis de salvação e ao limite máximo do dano exculpável -, o CPM se demite inteiramente da incumbência de estabelecer quaisquer critérios, dispondo que o direito sacrificado pode mesmo ser "superior ao direito protegido, desde que não lhe era razoavelmente exigível conduta diversa". No item 3, pontuamos que a coação moral irresistível é modalidade de EN que a lei brasileira tratou destacadamente. No entanto, o art. 22 tampouco contém indicação clara do limite máximo da atuação do coato: ali se diz apenas que o executor é isento de pena "se o fato é cometido sob coação irresistível"; o art. 65, III, c, por sua vez, manda reduzir a pena do agente que atuou "sob coação a que podia resistir"119. A literatura, por fim, pouco aprofundou a compreensão desse art. 22, geralmente se bastando com referências às ideias de inexigibilidade e de extraordinariedade ${ }^{120}$.

Neste contexto, dado o modesto escopo deste estudo, tampouco postularemos um limite intransponível para o EN exculpante, nem tentaremos estabelecer critérios de definição dos bens cuja proteção é apta a exculpar ${ }^{121}$, e apenas enfatizaremos as exigências de extraordinariedade e da inexistência de desproporção excessiva entre o mal evitado e o causado ${ }^{122}$. Uma vez afirmada a adequação típica de uma conduta, e constatada sua contrariedade ao Direito, a regra é que se exija a abstenção daquele comportamento: conforme advertido por Silva, apoiando-se em Hruschka, inexigíveis são os comportamentos supererrogatórios (como prestar socorro a um desconhecido mesmo com risco pessoal, isto é, fora das hipóteses do art. 135), e não o mero cumprimento da lei ${ }^{123}$. Cremos que um parâmetro pode ser a tantas vezes referida "tabula unius capax": matar para não morrer, em situação de perigo inevitável etc., é uma conduta exculpada; esse o arquétipo a ter em mente na interpretação da imagem, tão eloquente quanto

em causa própria ou em favor de parentes ou pessoas próximas exige o recurso à supralegalidade: v., entre vários outros, WESSELS/BEULKE/SATZGER, ob. cit. (nota 16), n. 677, p. 318. Sobre a opinião de Souza contrária à limitação legal do rol de possíveis agentes no EN exculpante, v. a nota 138 adiante.

119 Crítico do laconismo da lei, especialmente quando comparada com a disciplina do EN no CP/1969, SOUSA, ob. cit. (nota 29), p. 216.

120 V., p. ex., HUNGRIA, ob. cit. (nota 19), n. 89, p. 258; JESUS, ob. cit. (nota 13), p. 538. Destaquem-se, porém, os esforços de EISELE, ob. cit. (nota 5), p. 592 e 594, e ZAFFARONI/BATISTA/SLOKAR/ALAGIA, ob. cit. (nota 4), p. 336.

121 Veja-se o esforço de detalhamento em ZAFFARONI/PIERANGELI, ob. cit. (nota 12), n. 382, p. 563; DIAS, ob. cit. (nota 18), cap. $22^{\circ}, \S 24$, p. 617; e CEREZO MIR, ob. cit. (nota 10), p. 692.

122 JESCHECK/WEIGEND, ob. cit. (nota 88), § 44 II 1, p. 519; CEREZO MIR, ob. cit. (nota 10), p. 694; PERRON, ob. cit. (nota 27), p. 185 e 198; WESSELS/BEULKE/SATZGER, ob. cit. (nota 16), n. 659, p. 304; ESER/ BURKHARDT, ob. cit. (nota 51), caso 18, A 33, p. 379; SOUSA, ob. cit. (nota 29), p. 68 e 248; HIRSCH, ob. cit. (nota 64), p. 140.

123 SILVA SÁNCHEZ, ob. cit. (nota 69), p. 239. 
enganosa, de que o Direito não pode exigir que as pessoas se comportem como heróis ${ }^{124}$.

Assim vistas as coisas, o EN exculpante poderia resumir-se na seguinte cláusula hipotética:

Considera-se em estado de necessidade exculpante quem pratica o fato para salvar de perigo atual, que não provocou por sua vontade, nem podia de outro modo evitar, relevante direito próprio ou de pessoa próxima, sob circunstâncias em que não Ihe era exigível abster-se da ação salvadora. Em casos extremos, a exigência de proximidade do agente ao beneficiário da ação pode ser dispensada. ${ }^{125}$

Com a aceitação de um EN exculpante inspirado nos arts. 22 e 348, § 2으, do CP e no art. 39 do CPM, atende-se à intenção do legislador de deixar impune o náufrago que disputa a "tabula unius capax". Resta analisar o que significa o alegado prejuízo ao réu consistente na redução da justificação em simples exculpação (item 2.1). Há quatro implicações imediatas nessa transformação ${ }^{126}$. A primeira se refere ao conteúdo do pronunciamento judicial: ao meramente exculpar o autor, o juiz, em vez de reconhecer que o réu agiu de acordo com o Direito, apenas demonstra indulgência com a transgressão por ele cometida. Contudo, a sonoridade do argumento se reduz bastante quando se recorda que, no sistema unitário justificante, o EN reconhecido em favor do náufrago não constitui a solução definitiva do conflito, pois assegura simples faculdade (Hungria) que não impõe um dever de tolerância pelo afetado e pela comunidade em geral (item 1). Como já visto, no sistema unitário ambos os náufragos disputantes da "tabula unius capax" contariam com mesmo reconhecimento da licitude de sua conduta. $\mathrm{E}$, se ambos os contendores têm razão, é porque nenhum deles a tem por inteiro. Consequentemente, o que se transforma em exculpação (aos olhos de quem vê justificação na conduta dos náufragos antagonistas) não é uma justificação plena e irretorquível, como a da legítima defesa, mas uma justificação acanhada e parcial.

124 Novamente, a crítica é de SILVA SÁNCHEZ, ob. cit. (nota 69), p. 239. Noronha fala em "santo ou mártir" (NORONHA, ob. cit. [nota 9], p. 229). Recorrendo à comparação da abstenção da prática do injusto penal com um ato de heroísmo, BITENCOURT, ob. cit. (nota 13), cap. XXI, item 5.

125 Compare-se com a fórmula proposta de lege ferenda de Luís Greco e colaboradores: "É isento de pena quem comete fato ilícito para salvar de perigo atual, não evitável de outro modo, a vida, a integridade física ou a liberdade de locomoção ou sexual próprias, de cônjuge, companheiro, irmão, ascendente ou descendente, ou de outra pessoa com quem possua laços estreitos" (GRECO et al., ob. cit. [nota 101], p. 36).

126 Para uma breve comparação direta entre justificação e exculpação no EN, WESSELS/BEULKE/SATZGER, ob. cit. (nota 16), n. 663, p. 306. 
Em segundo lugar, alega-se que o reconhecimento da justificação põe o agente a salvo de reações em legítima defesa, às quais ele fica sujeito caso sua conduta seja apenas exculpada ${ }^{127}$. No entanto, é duvidoso que a vítima da ação exculpada, conhecedora da situação exculpante, possa exercer a legítima defesa em sua plenitude. Como já referido na nota 27 , a exigência de proporcionalidade é mínima na legítima defesa, porque o direito não deve ceder frente ao injusto. Mas esse fundamento não tem impedido que se imponham restrições pontuais ao direito de defesa, geralmente reunidas sob a epígrafe "restrições ético-sociais". Assim, aquele que atua sob o EN exculpante se sujeita à legítima defesa, mas os limites desta tendem a se aproximar aos do próprio EN justificante ${ }^{128}$. Uma restrição semelhante é admitida de longa data quanto às agressões injustas de inimputáveis ${ }^{129}$.

A terceira implicação se refere antes aos partícipes que ao autor: se o estado de necessidade é meramente exculpante, então quem presta auxílio ao autor se sujeita a punição, em razão do critério da acessoriedade limitada ${ }^{130}$. Gimbernat invocou essa consequência para defender a teoria unitária justificante no Direito espanhol (e, em particular, a justificação no conflito de bens iguais), argumentando haver uma contradição em aceitar que terceiro cometa de mão própria o homicídio de um dos náufragos para salvar o outro, e simultaneamente punir quem pratica um ato de menor intensidade, consistente em prestar ajuda ao náufrago homicida ${ }^{131}$. No entanto, incidem aqui os mesmos motivos que nos fizeram rejeitar a impunidade do auxílio necessário no conflito de bens iguais (item 4.1); em particular, se a participação do terceiro se revelar decisiva para o desfecho da disputa, ele terá decidido quem vive e quem morre tanto quanto se praticasse ele mesmo o fato típico ${ }^{132}$.

Para o autor da conduta praticada sob estado de necessidade, a consequência prática mais relevante da opção entre a justificação e a exculpação é a sua sujeição à medida de segurança, caso se reconheça que o fato não foi jus-

127 BRUNO, ob. cit. (nota 9), p. 393.

128 Sobre essas restrições (embora não tratando do caso de agressões injustas exculpadas), ZILIO, LH-Cirino dos Santos, p. 952-966.

129 Ainda que pela própria exclusão do direito à legítima defesa e aplicação direta das regras do EN (HUNGRIA, ob. cit. [nota 19], n. 92, p. 276; n. 95, p. 296).

130 BRUNO, ob. cit. (nota 9), p. 393.

131 GIMBERNAT ORDEIG, ob. cit. (nota 54), p. 222.

132 Crítico da solução de Gimbernat para o partícipe, CEREZO MIR, ob. cit. (nota 10), p. 682. Também contra a impunidade da participação do terceiro [sem relação com os envolvidos] que intervém no conflito entre vidas, ZAFFARONI/PIERANGELI, ob. cit. (nota 12), n. 338, p. 512; n. 341, p. 514. 
tificado e o autor era inimputável. Ainda assim, essa consequência pressupõe a discutível desconsideração, para os inimputáveis, da presença de uma causa de exculpação ${ }^{133}$.

Por fim, um aspecto ocasionalmente mencionado para explicar a diferença entre justificação e exculpação é o dever de indenizar. Contudo, observa-se que responsabilidade civil no EN tem regras próprias (cf. nota 90), que não exigem a ilicitude da ação lesiva para a imposição do dever de indenizar, razão pela qual até mesmo um defensor da teoria unitária justificante desconsidera esse aspecto ${ }^{134}$.

As considerações supra talvez sugiram certa indiferença nossa em relação à distinção entre justificação e exculpação. Não é esse, porém, o caso ${ }^{135}$. Trata-se apenas de destacar que a distinção possui reflexos não apenas para o autor da conduta sub judice, mas também para os demais implicados e para a própria coerência interna do sistema. Sinteticamente, cremos que reputar justificada a ação de cada um dos náufragos que disputa a "tabula unius capax" é mais problemático do que reconhecer abertamente que essa justificação não dá razão ao náufrago sobrevivente; que uma pessoa não pode matar outra para salvar-se; e que nesse caso ocorre apenas a exculpação ${ }^{136}$.

\section{Considerações finais}

Resumidamente, a proposta esboçada no texto consiste em conferir uma interpretação unitária ao art. 24 e inseri-lo em um modelo diferenciador, reduzindo o âmbito do dispositivo legal aos limites máximos aceitáveis de uma autêntica justificação. Tal solução nos parece atender melhor às exigências de um conceito coerente de justificação e de fixação dos limites do EN, os quais permanecem demasiadamente vagos à falta de uma concretização mais dirigida da noção de exigibilidade.

133 Como propõe, em Portugal, DIAS, Direito Penal português II, § 729, p. 461; a favor da dispensa da medida de segurança para o inimputável favorecido pelo estado de necessidade exculpante, ZAFFARONI, ob. cit. (nota 76), n. 507, p. 233; BITENCOURT, ob. cit. (nota 13), cap. XXIII, n. 1.6.

134 GIMBERNAT ORDEIG, ob. cit. (nota 54), p. 221, nota 12.

135 Para uma recente e vigorosa defesa da distinção, GRECO, Anatomia do crime 2, p. 9-25.

136 "Si la cuestión [da distinção entre justificação e exculpação] nos resulta tan interesante a los teóricos es porque en su resolución entran en juego distinciones básicas para la construcción de un sistema de imputación de responsabilidad penal internamente coherente." (ORTIZ DE URBINA GIMENO, ob. cit. [nota 99], p. 179) 
No resultado, a construção do texto aproxima o regime do EN do CP comum e a disciplina do CPM, o que nos parece um ganho: embora tal aproximação nem sempre seja possível ${ }^{137}$, cremos ser salutar o esforço de conciliação das legislações, naquilo que não atentar contra as peculiaridades do Direito Penal Militar nem contra o texto da lei. Todavia, a presente proposta não se identifica inteiramente com a solução do CPM, idêntica à do CP/1969, na medida em que tentamos aproveitar, como dito no início do item 6.1, a flexibilidade oferecida pelo texto do art. 24, para introduzir na ponderação de interesses todos os aspectos relevantes para o juízo de licitude ou ilicitude do fato. O CPM, por sua vez, alude apenas à "natureza e importância" dos males em comparação, ficando a meio caminho, em um certo sentido, entre a comparação de bens e a de interes$\operatorname{ses}^{138}$.

Certamente, são possíveis outras propostas, tanto nos seus moldes gerais quanto no esforço de compatibilização com a lei vigente. O modelo esboçado no texto se prende fortemente à ideia de que uma autêntica causa de justificação resolve em definitivo o conflito e se impõe a todos (e em especial aos diretamente afetados). Já na Espanha, por exemplo, alguns autores enxergam justificação no conflito de bens iguais, mesmo sem exigência expressa da lei daquele país ${ }^{139}$. Dos

137 O CPM contém, por exemplo, uma autorização geral para a punição da tentativa nas mesmas penas do crime consumado, o que não ocorre no CP comum (arts. 30, parágrafo único, e 14, parágrafo único, respectivamente). Assim, não aderimos inteiramente à argumentação de Galvão, para quem o conflito de bens iguais não deve ser subsumida ao EN justificante porque o CPM dispõe em sentido contrário e, "sendo o sistema harmônico, não é possível admitir respostas diferenciadas para a questão" (GALVÃO, ob. cit. [nota 3], n. 7.9.1.1, p. 433): consideramos a harmonização entre o DP comum e o DP Militar um objetivo louvável, mas cuja consecução é limitada pelo texto expresso de cada Código.

138 Decerto o comentário mais detalhado da disciplina do CP/1969 para o EN é o de Sousa, que já no seu título propunha "aplicações mais amplas". Como o próprio autor reconhece, sua pretensão de amplitude é satisfeita caso se interprete o termo "males" do CP/1969 no sentido de interesses, considerados em todas suas circunstâncias, e não simplesmente como bens (SOUSA, ob. cit. [nota 29], p. 239). Uma vez que se avance da ponderação entre bens para a ponderação de todos os interesses e circunstâncias contrapostos, contorna-se a alegação de que a exigência de considerável superioridade do mal evitado é incompatível com o regime do aborto necessário (ob. cit., p. XV, 132, 228 e 240, entre outras), resolvem-se os casos de salvação de vida de uns à custa da vida de outros que igualmente morreriam sem a intervenção (ob. cit., p. 170 e 229; v. nota 91, supra), e se dá solução adequada às situações em que, apesar da superioridade do bem salvo, existem razões adicionais, tais como a autonomia e dignidade da vítima, para inibir o reconhecimento do EN (cf. nota 100, supra). Outrossim, a insatisfação de Sousa com o art. 28 do $\mathrm{CP} / 1969$ também se deve à incorreta aplicação do dispositivo à colisão de deveres (ob. cit., p. 172 e 229), que se rege por princípios próprios e para a qual, de fato, é inadequada a exigência de que o bem salvo (ou melhor, o dever afinal cumprido) seja consideravelmente superior ao bem sacrificado (rectius: ao dever descumprido) - cf. nota 64, supra. Já em matéria de exculpação, Souza criticou a exigência, para o auxílio necessário, de parentesco ou relação de afeição entre agente e beneficiário (ob. cit., p. XVI, 207, 235, 241 e 252), defendendo a exculpação por imperativos de consciência em determinadas circunstâncias.

139 GIMBERNAT ORDEIG, ob. cit. (nota 54), passim. A proposta de Gimbernat - decerto o mais comentado defensor da teoria unitária na Espanha - se baseia em um critério próprio de distinção entre justificação e exculpação, 
modelos discrepantes, parece-nos exigível, sobretudo, que ofereçam soluções justas (além, é claro, de compatíveis com a lei vigente) para o conflito de bens iguais não existenciais e para a amplitude das faculdades concedidas no caso de auxílio necessário.

\section{Referências}

ALBAN CERQUEIRA, Rafaela de O. Inexigibilidade de conduta diversa no pós-finalismo: uma nova perspectiva principiológica. Dissertação (Mestrado em Direito) - Faculdade de Direito, Universidade Federal da Bahia. Salvador, 2014. Disponível em: https://repositorio.ufba.br/ri/handle/ri/16607.

ALBAN CERQUEIRA, Rafaela. Uma releitura do conceito analítico de crime através do princípio da exigibilidade. Tese (Doutorado em Direito) - Faculdade de Direito, Universidade Federal da Bahia. Salvador, 2019. Disponível em: https://repositorio.ufba. br/ri/handle/ri/30718.

ANDREUCCI, Ricardo Antunes. Coação irresistível por violência. São Paulo: José Bushatsky, 1974.

ANTÓN ONECA, José. Derecho Penal. 2. ed. Madrid: Akal, 1986.

BACIGALUPO, Enrique. Derecho Penal: Parte General. 2. ed. Buenos Aires: Hammurabi, 1999.

BALDÓ LAVILLA, Francisco. Estado de necesidad y legítima defensa: un estudio de las "situaciones de necesidad" de las que derivan facultades y deberes de salvaguarda. Barcelona: J. M. Bosch, 1994.

BARJA DE QUIROGA, Jacobo López. Tratado de Derecho Penal: Parte General. Madrid: Civitas, 2010.

que só foi acatado pelos seus discípulos. Vejam-se as críticas em HIRSCH, ob. cit. (nota 64), p. 126; HIRSCH, ob. cit. (nota 14), p. 31; ROXIN, ob. cit. (nota 18), p. 600; CEREZO MIR, ob. cit. (nota 10), p. 677; CUELLO CONTRERAS, ob. cit. (nota 14), cap. X, n. 162, p. 844. Além, disso, a exata compreensão das propostas ditas unitárias justificantes na Espanha exige a percepção de dois fatos: (1) seus adeptos frequentemente se abstêm de comentar o problema da salvação do bem mais valioso à custa do menos valioso (como observa, a propósito da exposição de Gimbernat, SILVA SÁNCHEZ, ob. cit. [nota 69], p. 234); (2) o Código Penal espanhol prevê a eximente do "miedo insuperable", o que demanda ressalva semelhante à feita no item 3 quanto à verdadeira pureza do sistema unitário proposto pelos autores citados. Considerando o "miedo insuperable" um estado de necessidade exculpante, BUSATO, ob. cit. (nota 35), p. 483. Ainda na Espanha, Robles esboçou o emprego da inexigibilidade como fórmula justificante, relacionada a situações em que o ordenamento não dispõe de recursos para resolver o conflito (ROBLES PLANAS, ob. cit. [nota 110], p. 117). São evidentes os ecos das teorias do espaço livre de regulação jurídica e da neutralidade, implicitamente rejeitadas no texto, e o próprio Robles, no texto que pudemos consultar, não desenvolve o tema (ob. e loc. cit.). 
BATISTA, Nilo. A tábua dos náufragos no Direito Penal brasileiro. In: PASCHOAL, Janaína Conceição; SILVEIRA, Renato de Mello Jorge (Coord.). Livro homenagem a Miguel Reale Júnior. Rio de Janeiro: GZ, 2014. p. 509-513.

BITENCOURT, Cezar Roberto. Tratado de direito penal. 27. ed. São Paulo: Saraiva, v. 1, 2021. Edição digital.

BITENCOURT, Cezar Roberto; MUÑOZ CONDE, Francisco. Teoria geral do delito. São Paulo: Saraiva, 2000.

BRUNO, Aníbal. Direito penal. 3. ed. Rio de Janeiro: Forense, t. I, 1967.

BRUNO, Aníbal. Direito penal. 3. ed. Rio de Janeiro: Forense, t. II, 1967.

BRUNO, Aníbal. Direito penal. Rio de Janeiro: Forense, t. IV, 1966.

BUSATO, Paulo César. Direito penal: parte geral. São Paulo: Atlas, 2013.

CANO PAÑOS, Miguel Ángel. Caso de la Luftsicherheitsgesetz. In: SÁNCHEZ-OSTIZ GUTIÉRREZ, Pablo (Org.). Casos que hicieron doctrina en Derecho penal. 2. ed. Madrid: La Ley, 2011. p. 911-934.

CARVALHO, Érika Mendes de. O favorecimento pessoal entre familiares (art. 348, $\S 2 .{ }^{\circ}$, do CP) como causa de inculpabilidade. Ciências Penais, São Paulo, n. 6, p. 174-198, 2007.

CEREZO MIR, José. Derecho Penal: Parte General. Obras completas. Lima/México, D.F.: Ara/Ubijus, t. I, 2006.

CHIESA, Luis E. Caso La Mignonette. In: SÁNCHEZ-OSTIZ GUTIÉRREZ, Pablo (Org.). Casos que hicieron doctrina en Derecho penal. 2. ed. Madrid: La Ley, 2011. p. 95-109.

CÓRDOBA RODA, Juan. Comentários ao artigo 8.7. In: CÓRDOBA RODA, Juan; RODRÍGUEZ MOURULLO, Gonzalo. Comentarios al Codigo penal. Barcelona: Ariel, t. I, 1972. p. 270-307.

CORREIA, Eduardo. Direito criminal. Coimbra: Almedina, v. II, 2000 (1965).

COSTA E SILVA, Antonio José da. Código Penal dos Estados Unidos do Brasil commentado. São Paulo: Companhia Editora Nacional, v. I, 1930. [Consultado no fac-símile disponível em: http://www2.senado.leg.br/bdsf/item/id/496204.]

COSTA E SILVA, Antonio José da. Comentários ao Código Penal brasileiro. 2. ed. São Paulo: Contasa, 1967.

COUSIÑO MAC IVER, Luis. Derecho penal chileno. Santiago: Editorial Juridica de Chile, t. II, 1979. 
CUELLO CONTRERAS, Joaquín. Derecho Penal: Parte General. 3. ed. Madrid:

Dykinson, v. I, 2002.

CUERDA RIEZU, Antonio. La colisión de deberes em derecho penal. Madrid: Tecnos, 1984.

DELMANTO, Celso; DELMANTO, Roberto; DELMANTO JUNIOR, Roberto;

DELMANTO, Fabio M. de Almeida. Código Penal comentado. 9. ed. São Paulo: Saraiva, 2015. Edição digital.

DIAS, Jorge de Figueiredo. Direito penal: parte geral. 2. ed. Coimbra/São Paulo: Coimbra Editora/Revista dos Tribunais, t. I, 2007.

DIAS, Jorge de Figueiredo. Direito Penal português, Parte Geral II: as consequências jurídicas do crime. Reimpressão. Coimbra: Coimbra Editora, 2005.

EISELE, Andreas. Direito penal: teoria do delito. Salvador: JusPodivm, 2018.

ESER, Albin; BURKHARDT, Björn. Derecho penal: cuestiones fundamentales de la Teoría del Delito sobre la base de casos de sentencias. Madrid: Colex, 1995.

FRAGOSO, Heleno Cláudio. Comentários ao Código Penal. 5. ed. Rio de Janeiro: Forense, v. I, t. II, 1978.

FRAGOSO, Heleno Cláudio. Lições de direito penal: a nova parte geral. 7. ed. Rio de Janeiro: Forense, 1985.

FRANCO, Alberto Silva. Comentários aos arts. 1ํa 40 do Código Penal. In: FRANCO, Alberto Silva; STOCO, Rui (Org.). Código Penal e sua interpretação. 8. ed. São Paulo: Revista dos Tribunais, 2007. p. 31-276.

FRISTER, Helmut. Derecho Penal: Parte General. Buenos Aires: Hammurabi, 2011. GALVÃO, Fernando. Direito penal: parte geral. 10. ed. Belo Horizonte: D’Plácido, 2018.

GARCIA, Basileu. Instituições de direito penal. 6. ed. São Paulo: Max Limonad, v. I, t. I, 1982.

GARCÍA CAVERO, Percy. Caso de la depresión reactiva. In: SÁNCHEZ-OSTIZ GUTIÉRREZ, Pablo (Org.). Casos que hicieron doctrina en Derecho penal. 2. ed. Madrid: La Ley, 2011. p. 129-142.

GIMBERNAT ORDEIG, Enrique. El estado de necesidad: un problema de antijuridicidad. In: GIMBERNAT ORDEIG, Enrique. Estudios de Derecho penal. 3. ed. Madrid: Tecnos, 1990. p. 218-230.

GLEIZER, Orlandino. Comentários de adaptação para o Direito brasileiro. In: HILGENDORF, Eric; VALERIUS, Brian. Direito penal: parte geral. Madrid/Barcelona/ Buenos Aires/São Paulo: Marcial Pons, 2019. 
GOLDSCHMIDT, James. El estado de necesidad, un problema de la culpabilidad. In: GOLDSCHMIDT, James. Derecho, Derecho penal y proceso: problemas fundamentales del Derecho. Madrid/Barcelona/Buenos Aires: Marcial Pons, t. I, 2010. p. 343-400.

GÓMEZ BENíTEZ, José Manuel. Teoría jurídica del delito: Derecho penal, Parte general. Madrid: Civitas, 1984 (1988).

GRECO, Luís. Contra a recente relativização da distinção entre injusto e culpabilidade. Anatomia do Crime, Coimbra, n. 2, p. 9-25, 2015.

GRECO, Luís. As regras por trás da exceção - Reflexões sobre a tortura nos chamados "casos de bomba-relógio". Revista Jurídica, Curitiba, v. 23, n. 7, p. 229-264, 2009. Disponível em: http://revista.unicuritiba.edu.br/index.php/RevJur/article/view/95/71. GRECO, Luís; HORTA, Frederico; LEITE, Alaor; TEIXEIRA, Adriano; QUANDT, Gustavo. Parte geral do Código Penal: uma proposta alternativa para debate. Marcial Pons, 2018.

GRECO, Rogério. Curso de direito penal: parte geral. 23. ed. Niterói: Impetus, v. I, 2021. HENKEL, Heinrich. Exigibilidad e inexigibilidad como principio jurídico regulativo. Buenos Aires-Montevideo: B de F, 2005.

HILGENDORF, Eric; VALERIUS, Brian. Direito penal: parte geral. Madrid/Barcelona/ Buenos Aires/São Paulo: Marcial Pons, 2019.

HIRSCH, Hans Joachim. La posición de la justificación y de la exculpación em la teoría del delito desde la perspectiva alemana. Bogotá: UEC, 1996.

HIRSCH, Hans Joachim. La regulación del estado de necesidad. In: HIRSCH, Hans Joachim. Derecho penal: obras completas. Buenos Aires: Rubinzal-Culzoni, t. I, 1999. p. 121-147.

HIRSCH, Hans Joachim. El Derecho Penal y el ámbito libre de regulación jurídica. In: HIRSCH, Hans Joachim. Derecho penal: obras completas. Buenos Aires: RubinzalCulzoni, t. I, 1999. p. 89-119.

HIRSCH, Hans Joachim. El estado de necesidad defensivo en la discusión alemana. In: HIRSCH, Hans Joachim. Derecho penal: obras completas. Buenos Aires: RubinzalCulzoni, t. V, 2011. p. 105-138.

HUNGRIA, Nélson; FRAGOSO, Heleno Cláudio. Comentários ao Código Penal. 5. ed. Rio de Janeiro: Forense, v. I, t. II, 1978.

JAKOBS, Günther. Derecho penal, Parte General: fundamentos y teoría de la imputación. 2. ed. Madrid: Marcial Pons, 1997.

JESCHECK, Hans-Heinrich; WEIGEND, Thomas. Tratado de Derecho penal: Parte General. Granada: Comares, 2002. 
JESUS, Damásio E. de. Comentários ao Código Penal: parte geral. 2. ed. São Paulo: Saraiva, v. 1, 1986.

JESUS, Damásio E. de. Direito penal. 36. ed. São Paulo: Saraiva, v. 1, 2015.

JESUS, Damásio E. de. Estado de necessidade. Ciência Penal, São Paulo, n. 1, p. 89-98, 1973.

JIMÉNEZ DE ASÚA, Luis. Princípios de Derecho penal: la ley y el delito. 3. ed. reimp. Buenos Aires: Abeledo-Perrot, 1997.

JIMÉNEZ DE ASÚA, Luis. Tratado de derecho penal. 2. ed. Buenos Aires: Losada, t. IV, 1961.

KAUFMANN, Armin. Dogmática de los delitos de omission. Madrid-Barcelona: Marcial Pons, 2006.

KAUFMANN, Arthur. Filosofia do Direito. 5. ed. Lisboa: Fundação Calouste Gulbenkian, 2014.

LEITE, Alaor. Erro, causas de justificação e causas de exculpação no novo Projeto de Código Penal (Projeto de Lei no 236/2012 do Senado Federal). Liberdades, n. especial (reforma do Código Penal), p. 59-97, 2012. Disponível em: https://ibccrim.org.br/ publicacoes/edicoes/452/7325.

LENCKNER, Theodor. Principle of balancing interests. In: ESER, Albin; FLETCHER, George P. (Org.). Rechtfertigung und Entschuldigung: rechtsvergleichende Perspektiven. Freiburg im Breisgau: Max-Planck Institut für ausländisches und internationales Strafrecht, 1987. p. 493-522.

LUCCHESI, Guilherme B. O Model Penal Code como chave de interpretação para o estudo comparado do Direito Penal americano. Revista Brasileira de Ciências Criminais, São Paulo, v. 178, p. 149-169, abr. 2021.

LUZÓN PEÑA, Diego-Manuel. Leciones de Derecho penal: Parte General. 2. ed. Valencia: Tirant lo Blanch, 2012. Edição digital.

MAÑALICH RAFFO, Juan Pablo. El estado de necesidad exculpante. Una propuesta de interpretación del artículo 10 no 11 del Código Penal chileno. In: WEEZEL, A. von (Ed.). Humanizar y renovar el Derecho Penal. Estudios en memoria de Enrique Cury. Santiago de Chile: Legal Publishing, Thomson Reuters, 2013. p. 715-742.

MARQUES, José Frederico. Tratado de direito penal. 2. ed. São Paulo: Saraiva, v. II, 1965.

MAURACH, Reinhart; ZIPF, Heinz. Derecho Penal: Parte General. Buenos Aires: Astrea, v. 1, 1994. 
MINORELLI, Lucas; CAETANO, Matheus de Almeida. Vida contra vida e colisão de deveres no contexto de Covid-19: o que os médicos precisam saber. Direito Público, Brasília, n. 94, p. 278-308, 2020. Disponível em: https://www.portaldeperiodicos.idp. edu.br/direitopublico/article/view/4636.

MINORELLI, Lucas; CEOLIN, Guilherme Francisco. Por que usar um exemplo clássico? Breves reflexões sobre o ensino jurídico-penal a partir da Tábua de Carnéades. Revista de Estudos Criminais, Porto Alegre, v. 18, n. 72, p. 147-170, 2019.

MIRABETE, Júlio Fabbrini. Código Penal interpretado. São Paulo: Atlas, 1999.

MIRABETE, Júlio Fabbrini. Manual de direito penal. 20. ed. São Paulo: Atlas, v. I, 2003. MIR PUIG, Santiago. Derecho Penal: Parte General. 8. ed. Barcelona: Reppetor, 2008. MOLINA FERNÁNDEZ, Fernando. El estado de necesidad como ley general: aproximación a un sistema de causas de justificación. Revista de Derecho Penal y Criminología [2a época], Madrid, n. extra 1, p. 199-260, 2000.

NORONHA, Edgard Magalhães. Direito penal: parte geral. 2. ed. São Paulo: Saraiva, v. 1, 1963.

$\mathrm{NUCCl}$, Guilherme de Souza. Curso de direito penal: parte geral. 3. ed. Rio de Janeiro: Forense, v. 1, 2019. Edição digital.

OCTAVIO DE TOLEDO Y UBIETO, Emilio; HUERTA TOCILDO, Susana. Derecho Penal, Parte General: Teoría jurídica del delito. 2. ed. Madrid: Rafael Castellanos, 1986.

ORTIZ DE URBINA GIMENO, Íñigo. Caso de los psiquiatras en el III Reich, p. 190. In: SÁNCHEZ-OSTIZ GUTIÉRREZ, P. (Org.). Casos que hicieron doctrina en Derecho penal. 2. ed. Madrid: La Ley, 2011. p. 177-192.

PACELLI, Eugênio; CALLEGARI, André. Manual de direito penal: parte geral. 5. ed. São Paulo: Atlas, 2019.

PEREIRA, José Hygino Duarte. Notas do tradutor. In: LISZT, Franz von. Tratado de direito penal allemão. Rio de Janeiro: F. Briguiet \& C., t. I, 1899. [Consultado no fac-símile disponível em https://www2.senado.leg.br/bdsf/handle/id/496219.]

PERRON, Walter. Justificación y exculpación en Derecho penal alemán en la exención de responsabilidad por situaciones especiales de necesidad: legítima defensa, estado de necesidad, colisión de deberes. Cuadernos de Doctrina y Jurisprudencia Penal, Buenos Aires, v. 3, n. 7, p. 167-206, 1997.

PRADO, Luiz Regis. O injusto penal e a culpabilidade como magnitudes graduáveis.

Revista Brasileira de Ciências Criminais, São Paulo, v. 27, p. 128-142, 1999.

PRADO, Luiz Regis. Tratado de direito penal brasileiro: parte geral. 3 ed. Rio de Janeiro: Forense, v. 1, 2019. Edição digital. 
QUANDT, Gustavo de Oliveira. Uma breve comparação entre o PLS 236/2012 e o Projeto Substitutivo: aplicação da lei penal e teoria do delito. In: LEITE, Alaor (Org.). Reforma penal: a crítica científica à parte geral do Projeto de Código Penal (PLS 236/2012). São Paulo: Atlas, 2015. p. 189-218.

REALE JÚNIOR, Miguel. Instituições de direito penal: parte geral. Rio de Janeiro: Forense, v. I, 2002.

ROBLES PLANAS, Ricardo. Caso del Leinenfänger. In: SÁNCHEZ-OSTIZ GUTIÉRREZ, Pablo (Org.). Casos que hicieron doctrina en Derecho penal. 2. ed. Madrid: La Ley, 2011. p. 111-127.

ROXIN, Claus. Las causas de justificación y de exculpación y su delimitación de otras causas de exclusión de la pena. In: ROXIN, Claus. Sistema del hecho punible/2: ilícito y justificación. Buenos Aires: Hammurabi, 2015. p. 585-617.

ROXIN, Claus. Derecho Penal, Parte General: fundamentos. La estructura de la teoría del delito. Madrid: Civitas, t. I, 1997.

ROXIN, Claus. El estado de necesidad defensivo desencadenado por seres humanos. In: ROXIN, Claus. Sistema del hecho punible/2: ilícito y justificación. Buenos Aires: Hammurabi, 2015. p. 465-505.

ROXIN, Claus. ¿Puede admitirse o al menos quedar impune la tortura estatal en casos excepcionales? Cuadernos de Política Criminal, Madrid, n. 83, p. 23-36, 2004.

SAINZ-CANTERO CAPARRÓS, José Eduardo. Comentário ao art. 20.5, p. 347. In: COBO DEL ROSAL, Manuel (Org.). Comentarios al Código Penal. [s.I.]: Edersa, t. II, 1999. p. 331-385.

SANTOS, Juarez Cirino dos. Direito penal: parte geral. 8. ed. Florianópolis: Tirant lo Blanch, 2018.

SILVA SÁNCHEZ, Jesús-María. Sobre el estado de necesidad en Derecho penal español. Anuario de Derecho Penal y Ciencias Penales, Madrid, v. 35, n. 3, p. 663-691, 1982. Disponível em: https://www.boe.es/biblioteca_juridica/anuarios_derecho/articulo. php?id=ANU-P-1982-30066300692.

SILVA SÁNCHEZ, Jesús-María. Sobre las situaciones de necesidad que no implican deberes de tolerancia. In: SILVA SÁNCHEZ, Jesús-María. Consideraciones sobre la teoría del delito. Buenos Aires: Ad-Hoc S. R. L., 1998. p. 221-257.

SIQUEIRA, Galdino. Direito penal brasileiro. Rio de Janeiro: Jacyntho, v. I, 1932. [Consultado no fac-símile disponível em https://www2.senado.leg.br/bdsf/handle/ id/496211.]

SOUSA, Alberto Rufino Rosa Rodrigues de. Estado de necessidade: um conceito novo e aplicações mais amplas. Rio de Janeiro: Forense, 1979. 
STRATENWERTH, Günter. Derecho penal, Parte General: el hecho punible. Buenos Aires: Hammurabi, v. I, 2005.

TOLEDO, Francisco de Assis. Princípios básicos de direito penal. 5. ed. São Paulo: Saraiva, 1994.

WESSELS, Johannes; BEULKE, Werner; SATZGER, Helmut. Derecho Penal: Parte General. El delito y su estructura. Lima: Instituto Pacífico, 2018.

WILENMANN, Javier. El fundamento del estado de necesidad justificante en el derecho penal chileno. Al mismo tiempo, introducción al problema de la dogmática del estado de necesidad en Chile. Revista de Derecho (Valdivia), v. 27, n. 1, p. 213-244, 2014. Disponível em: https://www.revistaderechovaldivia.cl/index.php/revde/issue/view/15. ZAFFARONI, Eugenio Raúl. Tratado de Derecho Penal: Parte General. Buenos Aires: Ediar, t. IV, 1982.

ZAFFARONI, Eugenio Raúl; BATISTA, Nilo; ALAGIA, Alejandro; SLOKAR, Alejandro. Direito penal brasileiro. Rio de Janeiro: Revan, v. II, II, 2017.

ZAFFARONI, Eugenio Raúl; PIERANGELI, José Henrique. Manual de direito penal brasileiro. Parte geral. 9. ed. São Paulo: Revista dos Tribunais, v. 1, 2011.

ZILIO, Jacson Luiz. As restrições ético-sociais do direito de legítima defesa. Uma leitura a partir dos fins preventivos e garantísticos do Direito Penal. In: ZILIO, Jacson Luiz; BOZZA, Fábio (Org.). Estudos críticos sobre o sistema penal: homenagem ao Professor Doutor Juarez Cirino dos Santos por seu 70ํaniversário. Curitiba: LedZe, 2012. p. 952-966.

\section{Conflito de interesses}

O autor declara a ausência de conflito de interesses na produção do presente trabalho.

\section{Sobre 0 autor:}

Gustavo de Oliveira Quandt | E-mail: tetsusan@hotmail.com

Mestre em Direito (UFPR). Defensor Público Federal.

Recebimento: 20.12.2021

Aprovação: 30.12 .2021 